\title{
Analysis of the transcriptome of bovine endometrial cells isolated by laser micro- dissection (2): impacts of post-partum negative energy balance on stromal, glandular and luminal epithelial cells
}

Wiruntita Chankeaw ${ }^{1,2}$, Sandra Lignier ${ }^{3}$, Christophe Richard ${ }^{3}$, Theodoros Ntallaris', Mariam Raliou³, Yongzhi Guo ', Damien Plassard ${ }^{4}$, Claudia Bevilacqua ${ }^{5}$, Olivier Sandra ${ }^{3}$, Göran Andersson $^{6}$, Patrice Humblot ${ }^{1}$ and

Gilles Charpigny ${ }^{3^{*}}$ (i)

\begin{abstract}
Background: In post-partum dairy cows, the energy needs to satisfy high milk production induces a status of more or less pronounced Negative Energy Balance (NEB). NEB associated with fat mobilization impairs reproductive function. In a companion paper, we described constitutive gene expression in the three main endometrial cell types (stromal, glandular and luminal epithelial cells) isolated by laser capture micro-dissection (LCM) showing the specificities of their transcriptomic profiles. This study investigates the specific impact of NEB on gene expression in these cells around 80 days after parturition at day 15 of the oestrus cycle and describes their specific response to NEB.

Results: Following the description of their constitutive expression, the transcriptome profiles obtained by RNA sequencing of the three cells types revealed that differences related to the severity of NEB altered mainly specific patterns of expression related to individual cell types. Number of differentially expressed genes between severe NEB (SNEB) and mild NEB (MNEB) cows was higher in ST than in LE and GE, respectively. SNEB was associated with differential expression of genes coding for proteins involved in metabolic processes and embryo-maternal interactions in ST. Under-expression of genes encoding proteins with functions related to cell structure was found in GE whereas genes encoding proteins participating in pro-inflammatory pathways were over-expressed. Genes associated to adaptive immunity were under-expressed in LE.
\end{abstract}

\footnotetext{
* Correspondence: gilles.charpigny@inrae.fr

${ }^{3}$ Université Paris-Saclay, UVSQ, INRAE, BREED, 78350 Jouy-en-Josas, France

Full list of author information is available at the end of the article
}

C C The Author(s). 2021 Open Access This article is licensed under a Creative Commons Attribution 4.0 International License, which permits use, sharing, adaptation, distribution and reproduction in any medium or format, as long as you give appropriate credit to the original author(s) and the source, provide a link to the Creative Commons licence, and indicate if changes were made. The images or other third party material in this article are included in the article's Creative Commons licence, unless indicated otherwise in a credit line to the material. If material is not included in the article's Creative Commons licence and your intended use is not permitted by statutory regulation or exceeds the permitted use, you will need to obtain permission directly from the copyright holder. To view a copy of this licence, visit http://creativecommons.org/licenses/by/4.0/. The Creative Commons Public Domain Dedication waiver (http://creativecommons.org/publicdomain/zero/1.0/) applies to the data made available in this article, unless otherwise stated in a credit line to the data. 


\begin{abstract}
Conclusion: The severity of NEB after calving is associated with changes in gene expression around 80 days after parturition corresponding to the time of breeding. Specific alterations in GEs are associated with activation of proinflammatory mechanisms. Concomitantly, changes in the expression of genes encoding proteins involved in cell interactions and maternal recognition of pregnancy takes place in ST. The combination of these effects possibly altering the uterine environment and embryo maternal interactions may negatively influence the establishment of pregnancy.
\end{abstract}

Keywords: Negative energy balance, Endometrium, Cell type-specific, Transcriptome, LCM, RNA-seq, Inflammation

\section{Background}

The existence of common genetic and epigenetic factors that influence metabolic imbalance, milk production and reproductive performance have been raised for long [1] and are still an important topic in dairy cow industry [2]. A significant decrease in fertility due to genetic improvement for increasing milk production has been reported for decades in dairy cows [3, 4]. Despite that a more balanced selection is currently applied [5], high milk-yield cows still meet strong negative energy balance (NEB) during the early postpartum period due to the high nutrient and energy demand for body metabolism, milk production, and body weight maintenance [6]. Energy deficiency and excessive lipid mobilization during the postpartum period have been reported to be the cause of unfavorable reproductive performances such as delayed ovarian activity [7], prolonged uterine involution period [8], retained placenta [9], endometritis [10], increased early embryonic losses and decreased conception rates [11].

Previous in vivo studies also showed the impacts of metabolic imbalance on gene expression in the endometrium during the early postpartum period $[12,13]$. Other studies have reported the effect of metabolic status on endometrial transcriptome of lactating cows during the time of recognition of pregnancy [14-16]. The results suggest that NEB associated with elevated concentrations of non-esterified fatty acids (NEFAs) induces infertility in postpartum cows through dysregulation of immune pathways [12]. This is consistent with the results of in vitro studies showing that NEFAs stimulate pro-inflammatory cytokine production and lipid accumulation of endometrial cells [17] and oviductal epithelial cells [18]. However, on the one hand, the information from these in vitro models, while obtained from a single cell type and not taking into account possible interactions between the different endometrial cell types may be too simplistic and need to be confirmed in vivo. On the other hand, the previous in vivo studies regarding the impact of NEB on uterine function and endometrial transcriptome were based on RNA prepared from biopsies taken from whole endometrial tissue sections without discriminating between different cell types. Thus, the understanding of molecular changes induced by NEB from entire endometrial tissues is still unclear and difficult to interpret functionally as responses may be affected by other cell types such as endothelial cells, smooth muscle cells and leukocytes [19].

The uterus is the site of intensive tissue remodeling during the estrous cycle, at time of implantation and placental development in response to the developing embryo [20]. Reciprocally, the control of the endometrium on embryo development steps has been recently documented in mice [21]. In the cow, histology of the endometrium shows a complex association of heterogeneous structures mainly consisting of luminal epithelial cells (LE), glandular epithelial cells (GE) as well as fibroblastlike stromal cells (ST) found in different proportions in caruncular and intercaruncular tissues [22]. These three cell types are functionally responsible for the embryo implantation process under the control of steroid hormones and act in different ways [23]. For instance, bovine uterine ST synthesize and release prostaglandin E-2 (PGE-2), involved in maternal recognition of pregnancy, whereas epithelial cells contribute less to such changes in prostaglandin levels [24]. Uterine epithelial cells play key roles for the establishment and maintenance of pregnancy through activation of the innate immune system and secretion of chemokines [25] that support the recruitment and activation of immune cells directed against pathogens. Moreover, LE and GE exhibit unique molecular signatures having cooperative roles at time of establishment of pregnancy [22, 26, 27]. Their morphology [28] and biochemical activity [29] differs at time of implantation. RNA-sequencing of the complete transcriptome for the three cell types has been described for equine cells [30]. Laser capture microdissection (LCM) has also been successfully used to retrieve two different uterine epithelial cell types to define the transcriptome and proteomic analysis of the ovine and porcine endometrium, respectively [31, 32]. In the accompanying paper we have demonstrated the importance of the differences in constitutive gene expression of the different endometrial cell types isolated from biopsies performed at day-15 of the estrous cycle [33]. In this second study we report results obtained from the same biological material showing the impacts of metabolic imbalance on the response of individual endometrial cell types at time 
of conception, which, to our knowledge has not previously been reported. We illustrate here differences in the transcriptomic profiles, obtained by RNAseq, of luminal epithelial cells, glandular epithelial cells and stromal cells, which were harvested by LCM between cows diagnosed with either MNEB or SNEB. The changes in gene expression observed between the two types of cows, suggest the existence of long-term impacts of NEB, which appear to be mostly cell type-specific.

\section{Results}

Feed intake, body condition score (BCS), plasma NEFA concentrations and milk progesterone concentration

Twelve cows in their second lactation were fed either a high or low energy diet from 30 days pre-partum. Energy balance calculations were used to classify cows as being in mild $(n=5)$ or severe $(n=4)$ negative energy balance groups (MNEB and SNEB). All cows were cyclic (one full cycle or more) before initiation of the synchronization treatment. Commencement of luteal activity was determined as day of first progesterone value above threshold of $3 \mathrm{ng} / \mathrm{ml}$ were not different $(22 \pm 5.6$ and $23.8 \pm 15.6$ days in the MNEB and SNEB groups, respectively, mean $\pm \mathrm{SD}$ ). Concentrations at time or 1 day before or after biopsy at day-15 were not different in the two groups and all cows were in luteal phase at this time. The evolution of residual feed intake with postpartum time in the two groups of cows is presented in (Fig. 1A). Throughout the full experimental period, the BCS of SRB cows in both NEB groups tended to decrease $(p=0.08)$. Mean BCS was $3.65 \pm 0.25$ at start of the experiment and $3.05 \pm 0.22$ at 120 days postpartum (Fig. 1B). However, NEB did not have a significant effect on BCS. Plasma NEFA concentrations did not differ between NEB groups over the full experimental period. However, SNEB cows presented higher NEFA plasma concentrations compared to MNEB cows at Day 15 prepartum and Day 15 post-partum $(p<0.05)$ (Fig. $1 C)$. Reduced BCS from 30 days pre-calving and 60 days postcalving was associated with the energy balance nadir $(r=-0.68, p<0.05)$. NEFA concentrations tended to be significantly associated with the residual feed intake values $(r=-0.28, p=0.06)$.

\section{Differential gene expression between the three endometrial cell types in NEB cows}

Endometrial biopsy samples used for analysis were collected at around 80 days post-partum on day 15 of a synchronized estrus cycle. The three endometrial cell types: luminal (LE), glandular (GE) epithelium and stromal cells (ST) were collected by laser microdissection from endometrial biopsies and the transcriptome profiles were obtained by RNA sequencing of the three cells types. Principal component analysis revealed differences in gene expression patterns in MNEB and SNEB cows for the three cell types (Fig. 2A). A clear separation between samples issued from the two groups of cows was observed in ST, whereas overlapping gene expression patterns appeared in GE and LE. The numbers of differentially expressed genes between MNEB and SNEB cows for each endometrial cell type are given in Table 1 and in the Venn diagram (Fig. 2B). The total number of differentially expressed genes (DEGs) in ST, GE and LE when comparing SNEB cows to MNEB cows were 1049, 24 and 52, respectively.

Seven DEGs were found as being common in ST and GE: BTG Anti-Proliferation Factor 2 (BTG2), Lymphocyte Antigen 6 Family Member G6C (LY6G6C), C-C Motif Chemokine Ligand 4 (CCL4) and JunB Proto-Oncogene, AP-1 Transcription Factor Subunit (JUNB), chemokine (C-C motif) ligand 3 (CCL3), chromobox protein homolog 1 and one pseudogene (ENSBTAG00000047824). Three DEGs were common between ST and LE: CRK ProtoOncogene, Adaptor Protein $(C R K)$, Plexin Domain Containing 1 (PLXDC) and Myotubularin related protein 10 (MTMR10). None of the DEGs were common to all three cell types. The list of over- and underexpressed mRNAs in ST, GE and LE are given in separate sheets of the additional file (TableS1_ DEGSNEBvsMNEB.xlsx). In SNEB animals, a large proportion of DEGs were identified as over-expressed in ST (72\%) and GE (63\%) whereas almost all DEGs were under-expressed in LE (98\%) (Table 1). An overview of the differential patterns of gene expression in ST, GE, and LE obtained by LCM between SNEB and MNEB cows are illustrated in volcano plots (Fig. 3A to $\mathrm{C})$.

\section{Under-expressed genes in ST}

Either by using the statistical over-representation test from PANTHER with reactome pathways annotation or by browsing pathways ontology classification, the analysis detected four main significant pathways from the 298 under-expressed genes (Table 2). A first group of genes encode proteins that are involved in the regulation of interferon signaling as well as in inflammation mediated by chemokine and cytokine (P00031). A second important group of underexpressed genes code for proteins with functions associated with the extracellular matrix and its degradation. A third group of genes code for proteins related to Wnt signaling pathway (P00057). In addition, genes of integrin signaling pathway (P00034) are over-represented. Around 10\% of under-expressed genes in ST from SNEB animals are genes involved in signal transduction (GO: 0007165) and cellular response to stimulus (GO: 0051716). 


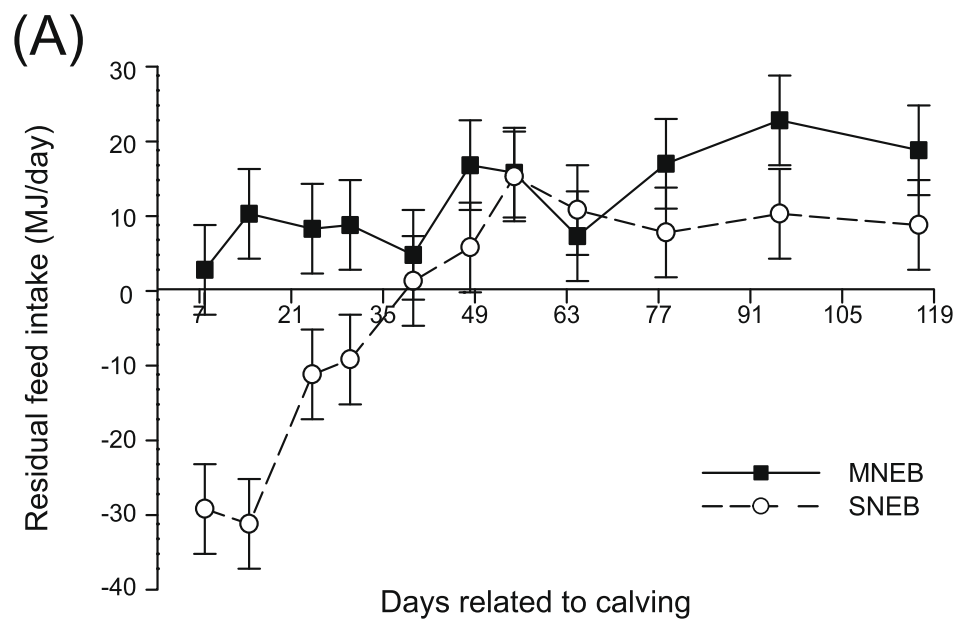

(B)

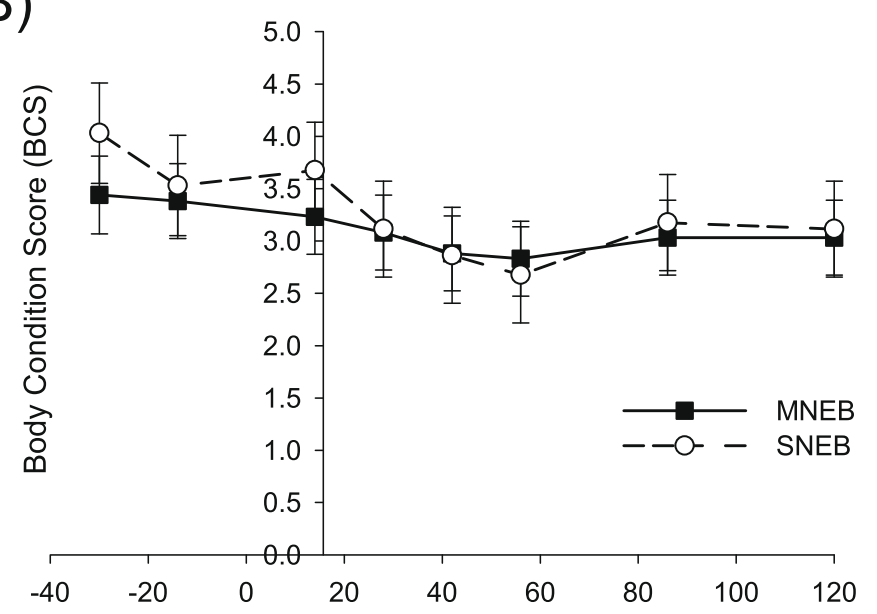

(C)

Days related to calving

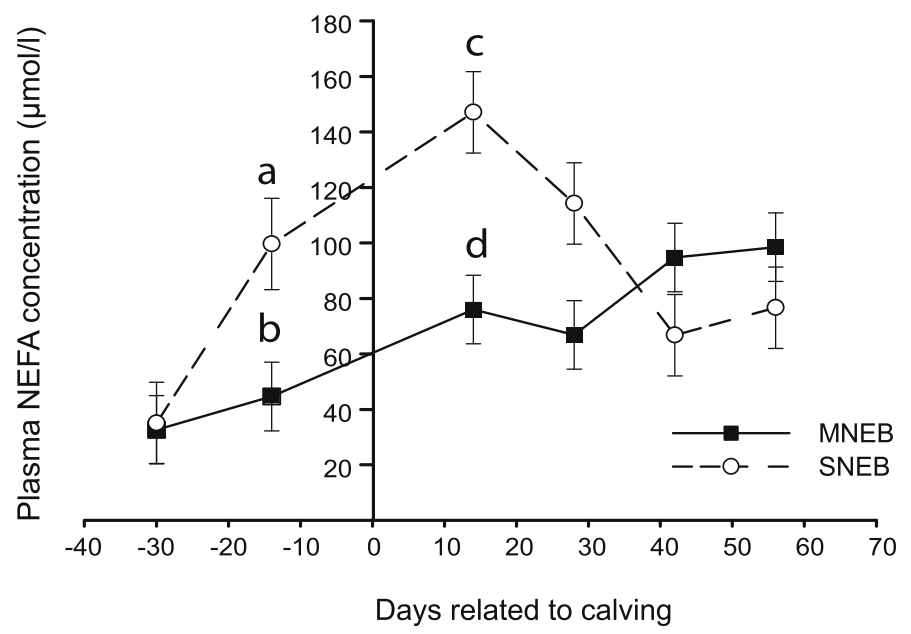

Fig. 1 Residual feed intake (A), Body Condition Score (B) and plasma NEFA concentrations ( $\mu$ mol//; LSmeans \pm s.e.m.) (C) of LCM-selected SRB cows between observed start of the experiment and 56 days after calving in MNEB ( $\mathbf{m}$ solid line; $n=5$ ) and SNEB (o dashed line; $n=4)$ group. Significant differences were observed at 15 days before (a vs $b ; p<0.05$ ), and 15 days after calving ( $c$ vs $d ; p<0.05$ ) 


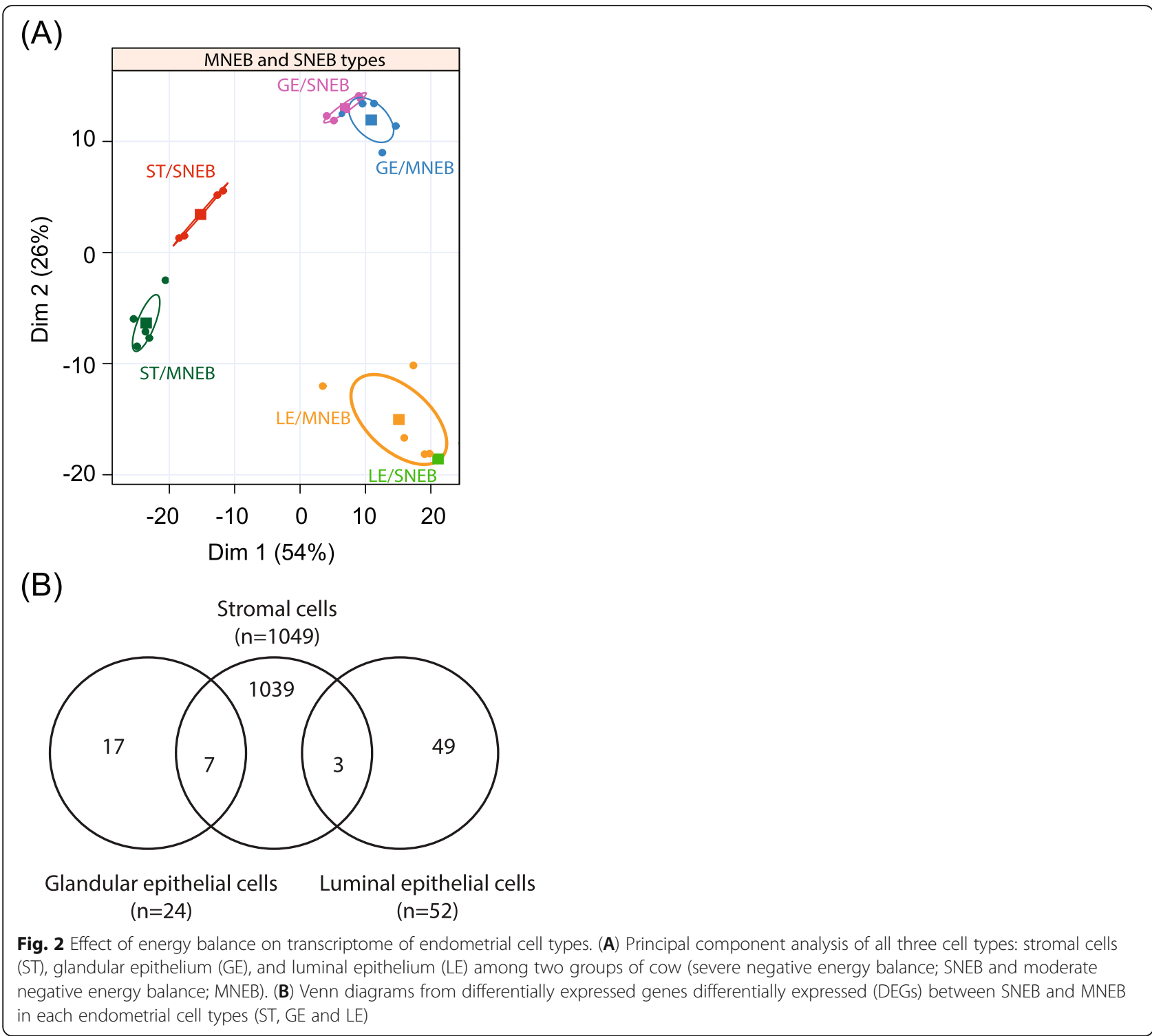

\section{Over-expressed genes in ST}

The GO molecular function annotation analysis using the PANTHER database (Table 3) indicates that $50 \%$ of the over-expressed genes from SNEB ST samples are distributed in three main categories: binding (GO:0005488) $(n=$ 186), catalytic activity (GO: 0003824) $(n=130)$ and transporter activity (GO:0005215) $(n=52)$. Binding categories

Table 1 Number of DEGs, which were identified as being overor under-expressed, presented in specific endometrial cell types (ST, GE and LE) of SNEB cows when compared to MNEB cows

\begin{tabular}{llll}
\hline Expression & Cell types & & \\
\cline { 2 - 4 } & ST & GE & LE \\
\hline Over & 751 & 15 & 1 \\
Under & 298 & 9 & 51 \\
Total & 1049 & 24 & 52 \\
\hline
\end{tabular}

includes cytoskeletal protein binding (GO: 0008092) $(n=$ 17), enzyme binding (GO: 0019899) $(n=24)$ and signaling receptor binding (GO: 0005102) $(n=21)$. Catalytic activity class includes genes involved in hydrolase activity (GO: 0016787) $(n=57)$ and transferase activity (GO: 0016740) $(n=47)$. In the transporter activity category $92 \%$ of genes are related to transmembrane transporter activity (GO: 0022857) and $8 \%$ to lipid transporter activity (GO: 0005319). Considering the PANTHER classification based on biological process annotation, the most frequently reported GO terms are cellular process (GO: 0009987; $n=$ 230), cell proliferation (GO: 0008283; $n=105)$, metabolic process (GO: 0008152; $n=101)$ and localization (GO: 0051179; $n=72)$.

The analysis from PANTHER pathways (Table 3) revealed that genes from three significant pathways are over-represented in ST from SNEB vs MNEB cows 


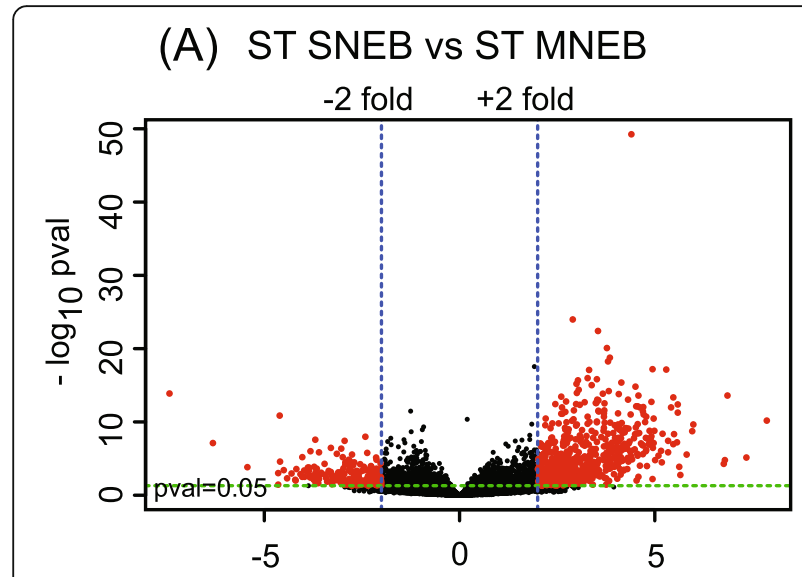

(B) GE SNEB vs GE MNEB

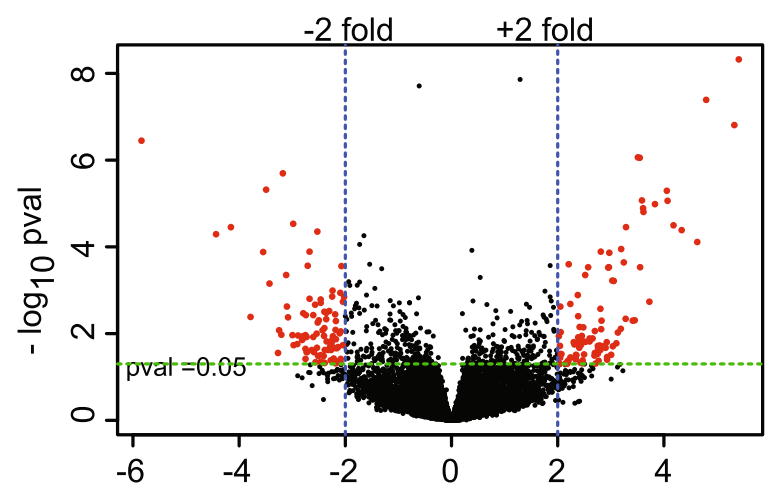

(C) LE SNEB vs LE MNEB

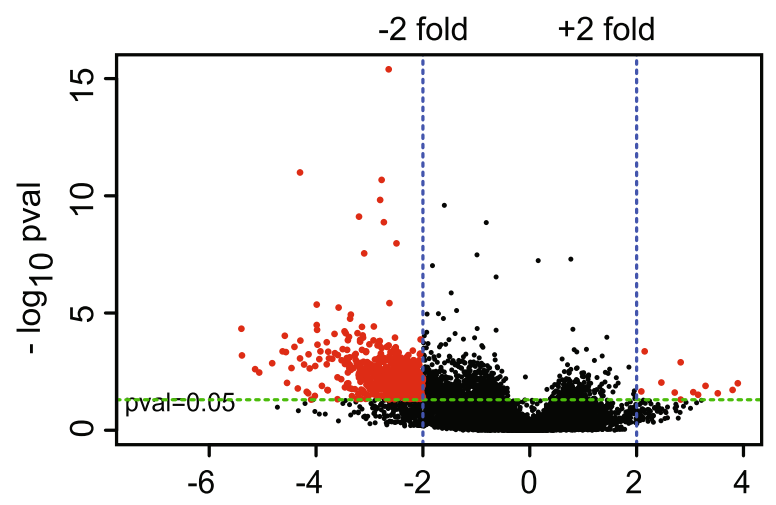

$\log _{2}$ fold change

Fig. 3 Volcano plots of distribution of differentially expressed genes between SNEB and MNEB for the three endometrial cell types ST (A), GE (B) and LE (C). The dotted lines in green and blue represent the cut-off, respectively for the statistical significance [-Log10 (P-value), $y$-axis] and for $+/-2$ log2fold change of gene expression [ $\mathrm{x}$-axis]. Differentially expressed genes are shown in red dots

including: (i) genes related to inflammation mediated by chemokine and cytokine signaling pathway (P00031); ii) genes involved in Wnt signaling pathway (P00057) and in cadherin signaling pathway (P00012); and (iii) genes associated to integrin signaling pathway (P00034). In addition, according to Biological Process classification, a positive enrichment was detected for genes related to cytoskeleton-dependent intracellular transport (GO: 0030705) and for cilium movement and dynein complex (GO:0003341). Finally, many genes involved in transport activity highlight the enrichment of transmembrane transporter activity (GO:0022857).

\section{Differential expression in GE}

Only nine known genes are under-expressed in GE cells from SNEB cows when compared to MNEB ones (NPPB, PTGFR, ANKS1B, CDH18, PPP1R1C, LY6G6C, MT1E, $A S B 16$ and $P R O M 2)$. Five are related to binding functions (PROM2, CDH18, NPPB, PTGFR and MT1E) and/ or involved in biological regulation $(C D H 18, N P P B$, PTGFR and MT1E). Due to the limited number of under-expressed genes, no enrichment could be detected in statistical overrepresentation test. Among the 15 over-expressed genes, three main pathways are overrepresented (Table 4). Four genes (JUNB, CCL2, CCL4 and CCL3) encode proteins with functions related to inflammation mediated by chemokine and cytokine signaling pathway (P00031 and GO:0070098). Four genes encoding immediate-early transcription factors (FOS, JUNB ATF3 and EGR2) are associated with numerous related annotation terms: RNA polymerase II proximal promoter sequence-specific DNA binding (GO: 0000978), DNA-binding transcription factor activity, RNA polymerase II-specific (GO:0000981). An additional enriched pathway is revealed (Gonadotropin-releasing hormone receptor pathway; P06664).

\section{Differential expression in LE}

In LE samples, only B4GALT5 is over-expressed in SNEB. No significant enriched GO terms is related to the under-expressed DEGs at FDR $p$ value $<0.05$. By using the raw P value instead FDR (Table 5), the analysis of under-expressed genes indicates some enrichments corresponding to signaling receptor binding (GO: 0005102), cytokine activity (GO:0005125) and steroid binding (GO:0005496). Other genes belonging to relevant pathways are highlighted by scanning the list of DEGs: defense response to bacterium (GO:0042742); signaling by PDGF (R-BTA-186797); Synthesis of Leukotrienes and Eoxins (R-BTA-2142691).

\section{KEGG pathway analysis of the DEGs}

Significantly enriched KEGG pathways from DAVID database were found in GE and ST, whereas no significant KEGG pathway was detected in LE (Table 6). In ST cells, DEGs between SNEB and MNEB cows were significantly enriched in four different KEGG pathways. 
Table 2 Gene Functional Classification Result (PANTHER 14.1) of under-expressed genes in ST cells from SNEB animals. Main pathways and ontology annotation groups enriched are shown (over-representation statistical test)

\begin{tabular}{|c|c|c|c|}
\hline PANTHER Classification & $\begin{array}{l}\text { fold } \\
\text { Enrichment }\end{array}$ & FDR & genes \\
\hline \multicolumn{4}{|l|}{ PANTHER Reactome Pathways } \\
\hline $\begin{array}{l}\text { Antiviral mechanism by IFN-stimulated } \\
\text { genes (R-BTA-1169410) }\end{array}$ & 24.99 & $\begin{array}{l}4.03 E- \\
05\end{array}$ & \multirow[t]{2}{*}{ MX2 PTPN2, JAK1, DDX58, EIF2AK2, IFIT1, ISG15, STAT1 } \\
\hline Interferon Signaling (R-BTA-913531) & 14.9 & $\begin{array}{l}9.55 \mathrm{E}- \\
05\end{array}$ & \\
\hline \multicolumn{4}{|l|}{ PANTHER GO-Slim Biological Process } \\
\hline defense response to virus (GO:0051607) & 19.04 & $\begin{array}{l}3.92 \mathrm{E}- \\
03\end{array}$ & MX2, OASIY, IFITI, OASIZ, MX2, MX1 \\
\hline Wnt signaling pathway (GO:0016055) & 6.07 & $\begin{array}{l}1.55 \mathrm{E}- \\
02\end{array}$ & SFRP4, APCDD1, LEF1, TLE4, SULF1, WNT6, DKK3, NID1 \\
\hline \multicolumn{4}{|l|}{ PANTHER Pathways } \\
\hline Regulation of IFNG signaling (R-BTA-877312) & - & - & \multirow{3}{*}{$\begin{array}{l}\text { RAPGEF1, MX1, EIF2AK2, UBA7, ISG15, PTPN2, MX2, DDX58, IL1RAP, IL16, CRK, IFIT1, } \\
\text { STAT1, IFNGR2, JAK1, STX3, NFATC1, ALOX12 }\end{array}$} \\
\hline $\begin{array}{l}\text { Cytokine Signaling in Immune system (R- } \\
\text { BTA-1280215) }\end{array}$ & - & - & \\
\hline $\begin{array}{l}\text { Antiviral mechanism by IFN-stimulated } \\
\text { genes (R-BTA-1169410) }\end{array}$ & - & - & \\
\hline $\begin{array}{l}\text { Extracellular matrix organisation (R-BTA- } \\
\text { 1474244) }\end{array}$ & - & - & \multirow[t]{2}{*}{ KLK1, TPSB1, COL4A4, COL2A1, MMP19, NID1, COL6A6, COL4A3, COL26A1 } \\
\hline $\begin{array}{l}\text { Collagen chain trimerization (R-BTA- } \\
8948216 \text { ) }\end{array}$ & - & - & \\
\hline Wnt signaling pathway (P00057) & - & - & CDH11, TLE4, LEF1, NFATC1, PRKCH, SMARCD2, FBXW7) \\
\hline Integrin signaling pathway (P00034) & - & - & ITGA5, ITGA10, RAPGEF1, MAP 3 K5, CRK \\
\hline Cadherin signaling pathway (P00012) & - & - & CDH11, LEF1, CDH12, CDH2, WNT6, WNT4 \\
\hline Apoptosis signaling pathway (P00006) & - & - & EIF2AK2, RIPK1, PRKCH, MAP 3 K5 \\
\hline
\end{tabular}

Furthermore, the David database recognized 25 different KEGG pathways with the overexpressed genes. Two were found significantly enriched. They are related to calcium signaling pathway (KEGG map 04020, fold enrichment $=3.4 ; 17$ DEGs) and tight junctions (KEGG map 04530; fold enrichment $=4.8 ; 11$ DEGs. With under-expressed DEGs, two KEGG pathways associated with viral infectious diseases (KEGG "measles" map 05162 and KEGG "Influenza A" map 05164; fold enrichment respectively $=5.0$ and $4.1 ; 11$ DEGs) are overrepresented (Table 6). The names of these two KEGG pathways do not make sense with endometrial physiology. The genes of these pathways are known to be important members of interferon signaling that is a critical mechanism for establishment of pregnancy (reactome pathways: BTA-913531, BTA-877312). For glandular epithelium, over-expressed DEGs matched to 10 overrepresented KEGG pathways. The KEGG TNF signaling pathway (KEGG map 04010) was the only one found to be significantly enriched (Fold enrichment = 21.5). In contrast, no enriched KEGG pathways were found from the set of under-expressed DEGs.

The corresponding STRING-generated interaction network obtained from DEGs belonging to the 5 KEGG pathways associated to ST and GE cells revealed strong interactions (PPI enrichment value $<1.0 \mathrm{E}-16$ ) between these sets of DEGs that are related to the JAK/STAT signaling (Fig. 4).

\section{Discussion}

During negative energy balance (NEB), lipolysis in adipose tissue is increased resulting in decreased BCS and increased NEFAs in blood [34]. Changes in BCS and NEFA concentrations were correlated with NEB nadir and plasma NEFA concentrations in SNEB cows were greater than in MNEB cows in the pre-partum and early post-partum. Both observations are consistent with earlier findings [35] and shows that the two groups were in a different metabolic status before and during the two first weeks post-partum. The impacts of NEB on bovine reproductive performances are well documented [36]. A wealth of information illustrates the negative effects of NEB and NEFA on ovarian cells [37], embryos [38] and oviduct [39]. On the contrary, relatively few publications have reported effects of NEB on the endometrial tissue or cells. In vivo studies showed that NEB had negative impacts on endometrial function through the alteration of immune response and activation of pro-inflammatory and IGF-insulin signaling pathways [12, 40]. However, in those 
Table 3 Gene Functional Classification Result (PANTHER 14.1) of over-expressed genes in ST cells from SNEB animals. Main pathways and ontology annotation groups enriched are shown (over-representation statistical test)

\begin{tabular}{|c|c|c|c|}
\hline PANTHER Classification & $\begin{array}{l}\text { fold } \\
\text { Enrichment }\end{array}$ & FDR & genes \\
\hline \multicolumn{4}{|l|}{ PANTHER Pathways } \\
\hline $\begin{array}{l}\text { Inflammation mediated by chemokine } \\
\text { and cytokine signaling pathway (P00031) }\end{array}$ & 2.15 & $\begin{array}{l}5.26 \mathrm{E}- \\
03\end{array}$ & $\begin{array}{l}\text { ACTA2, JUNB, CAMK2B, CCL11, MYH11, ACTG2, ITPR2, PRKCZ, MYH14, ACTA1, PLCB4, } \\
\text { MYLK, PAK4, PLCH1, CCL4, CCL3 }\end{array}$ \\
\hline Wnt signaling pathway (P00057) & 2.1 & $\begin{array}{l}2.58 \mathrm{E}- \\
02\end{array}$ & $\begin{array}{l}\text { ACTG2, FZD5, PLCB4, CDH3, PRKCZ, CDH1, ACTA1, CTBP2, ITPR2, FRZB, ANKRD6, } \\
\text { ACTA2 }\end{array}$ \\
\hline Cadherin signaling pathway (P00012) & 2.21 & $\begin{array}{l}3.43 \mathrm{E}- \\
02\end{array}$ & ACTA2, CDH3, ACTG2, FRK, FZD5, ACTA1, CDH1, ERBB3 \\
\hline Integrin signaling pathway (P00034) & 1.72 & $\begin{array}{l}1.51 \mathrm{E}- \\
02\end{array}$ & ACTG2, ITGB4, FRK, RAP2A, ITGB6, FLNA, COL4A6, ACTA1, FLNB, COL4A5, ACTA2 \\
\hline $\begin{array}{l}\text { Gap junction trafficking and regulation (R- } \\
\text { BTA-157858) }\end{array}$ & 4.98 & $\begin{array}{l}1.16 \mathrm{E}- \\
02\end{array}$ & $G J B 4, G J B 1, G J B 3, G J B 5$ \\
\hline $\begin{array}{l}\text { Cytoskeletal regulation by Rho GTPase } \\
\text { (P00016) }\end{array}$ & 3 & $\begin{array}{l}7.29 \mathrm{E}- \\
03\end{array}$ & ACTA2, MYH11, ACTG2, ARHGAP1, MYH14, ACTA1, MYLK, PAK4 \\
\hline \multicolumn{4}{|l|}{ PANTHER Biological Process } \\
\hline $\begin{array}{l}\text { cytoskeleton-dependent intracellular } \\
\text { transport (GO:0030705) }\end{array}$ & 3.49 & $\begin{array}{l}6.77 \mathrm{E}- \\
03\end{array}$ & $\begin{array}{l}\text { RP1, ACTA2, SPAG17, ACTG2, BICDL2, JHY, JHY, ACTA1, TEKT4, CENPJ, DYNC111, } \\
\text { CFAP54, CCDC39, DRC1, BICDL1 }\end{array}$ \\
\hline cilium movement (GO:0003341) & 7.88 & $\begin{array}{l}7.77 \mathrm{E}- \\
03\end{array}$ & DNAH7, ZBBX, TACR1, TEKT4, CCDC39, DNAH11, DRC1 \\
\hline \multicolumn{4}{|l|}{ PANTHER Molecular Function } \\
\hline $\begin{array}{l}\text { transmembrane transporter activity (GO: } \\
\text { 0022857) }\end{array}$ & 1.55 & $\begin{array}{l}1.54 \mathrm{E}- \\
02\end{array}$ & $\begin{array}{l}\text { LRRC26, SLC45A2, P2RX3, LRRC38, KCNG1, SLC36A2, SLC38A11, KCNMB1, CLCN3, } \\
\text { GRIN1, ATP1B1, ATP2B4, SLC18A2, SLC5A9, SLC29A2, CACNB2, GRIA3, KCNF1, } \\
\text { SLC5A10, SGK2, LRRIQ1, ATP6V1G3, SLC35A3, SLC4A7, SLC10A1, KCNH2, TMC5, } \\
\text { SLC31A2, SLC34A2 }\end{array}$ \\
\hline
\end{tabular}

studies and others [14-16] information was obtained from full tissue and to our knowledge, the present study is the first time that the specific effects of NEB on the three main cell types of the endometrium are reported.

\section{Impact of NEB on the three endometrial cell types}

Overall, our results show that NEB impacts mainly ST whereas GE and LE cells are less affected. More than $10 \%(13 \%)$ of the total number of genes expressed in ST were impaired by NEB status while less than $1 \%$ were affected in GE and LE (0.3 and 0.7\%, respectively). When considering the sub groups of genes showing a specific expression related to cell type, NEB did not affect any of those in GE and modified only the expression of TCN1 and B4GALT5 in LE cells. This number is probably under-estimated in LE due to the comparison restricted to a single sample in the SNEB group. By contrast, a relatively high number of genes (about $8 \% ; n=91$ ) specifically expressed by ST are affected by NEB.

\section{Impact of NEB on genes related to cytoskeleton and cell adhesion}

Genes encoding tropomyosins (TPM1 and TPM2) and myosins (MYO5C and MYO5B) proteins, which are

Table 4 Gene Functional Classification Result (PANTHER 14.1) of over-expressed genes in GE cells from SNEB animals. Main pathways and ontology annotation groups enriched are shown (over-representation statistical test)

\begin{tabular}{|c|c|c|c|}
\hline PANTHER Classification & fold Enrichment & FDR & genes \\
\hline \multicolumn{4}{|l|}{ PANTHER Pathways } \\
\hline Inflammation mediated by chemokine and cytokine signaling pathway (P00031) & 24.95 & $9.01 \mathrm{E}-04$ & JUNB, CCL2, CCL4, CCL3 \\
\hline Gonadotropin-releasing hormone receptor pathway (P06664) & 31.19 & $3.17 \mathrm{E}-05$ & JUNB, FOS, ATF3, NR4A1 \\
\hline Apoptosis signaling pathway (P00006) & 37.42 & 2.83E-03 & FOS, ATF3 \\
\hline \multicolumn{4}{|l|}{ PANTHER GO-Slim Biological Process } \\
\hline chemokine-mediated signaling pathway (GO:0070098) & $>100$ & $5.44 \mathrm{E}-04$ & JUNB, CCL2, CCL4, CCL3 \\
\hline \multicolumn{4}{|l|}{ PANTHER Molecular Function } \\
\hline DNA-binding transcription factor activity, RNA polymerase II-specific (GO:0000981) & 21.8 & $2.30 \mathrm{E}-04$ & JUNB, FOS, ATF3, EGR2 \\
\hline cytokine receptor binding (GO:0005126) & 36.04 & $1.75 \mathrm{E}-03$ & $C C L 2, C C L 4, C C L 3$ \\
\hline
\end{tabular}


Table 5 Gene Functional Classification Result (PANTHER 14.1) of over-expressed genes in LE cells from SNEB animals. Main pathways and ontology annotation groups enriched are shown (over-representation statistical test)

\begin{tabular}{|c|c|c|c|}
\hline PANTHER Classification & fold Enrichment & raw $P$ value & genes \\
\hline \multicolumn{4}{|l|}{ PANTHER GO-Slim Molecular Function } \\
\hline signaling receptor binding (GO:0005102) & 4.21 & $6.60 \mathrm{E}-03$ & BMP2, SEMA6D, IGHV2, NDP, TAP \\
\hline cytokine activity (GO:0005125) & 7.42 & 3.05E-02 & $B M P 2, N D P$ \\
\hline steroid binding (GO:0005496) & 25.23 & 3.13E-03 & PAQR8, OSBPL6 \\
\hline \multicolumn{4}{|l|}{ PANTHER GO-Slim Biological Process } \\
\hline response to steroid hormone (GO:0048545) & 37.97 & 2.79E-02 & PAQR8 \\
\hline defense response to bacterium (GO:0042742) & 10.07 & $1.75 \mathrm{E}-02$ & IGHV2, TAP \\
\hline \multicolumn{4}{|l|}{ PANTHER pathways } \\
\hline Signaling by PDGF (R-BTA-186797) & 44.52 & $5.36 \mathrm{E}-05$ & PTPN12, THBS4, CRK \\
\hline Synthesis of Leukotrienes (LT) and Eoxins (EX) (R-BTA-2142691) & 33.64 & $3.12 \mathrm{E}-02$ & CYPAB1 \\
\hline
\end{tabular}

structural constituents of cytoskeleton (GO: 0016459) were over-expressed in ST of SNEB cows. Similar overexpression of tropomyosins and myosins has been reported in the endometrium of fertile cows [41]. The increased expression of myosins was associated to overexpression of genes of the dynein family (DNAH5, DNAH7, DNAH11, DYNC1I1 and DYNLRB2), which encode proteins that are involved in cell mobility (GO: 0005874). The signification of these changes in the context of fertility deserves further investigations. In contrast, a large set of genes related to cell adhesion and cell-cell and cell-extracellular matrix adhesion [42], such as integrins (ITGA5 and ITGA10), cadherins (CDH2, CDH11 and CDH12), AGRN, EGFLAM, TGFBI, type IV collagen (COL4A4), type VIII collagen (COL8A1), ODZ3, SCARB2 and WISP3 were under-expressed in ST of SNEB cows. The lower expression of integrins could be seen as unfavourable to establishment of pregnancy. In humans, ITGB3 mRNA has been cited as a positive marker associated with pregnancy $[43,44]$. In sheep, elevated expression of ITGAV, ITGA4, and ITGA5 in GE has been found during pregnancy [45]. E-cadherin $(C D H 1)$ has been documented as a critical gene for embryo implantation as its under-expression in epithelial cells allows endometrial cells dissociation following blastocyst invasion [46]. Moreover, an increased expression of type IV collagens has been identified in endometrium of low fertility heifers [47], however, the opposite trend was found here in SNEB cows. In ST from the SNEB group, genes belonging to the Wnt pathway (P00057) were either over-expressed (ACTG2, FZD5, PLCB4, CDH3, PRKCZ, CDH1, ACTA1, CTBP2, ITPR2, FRZB, ANKRD6 and ACTA2) or under-expressed (CDH11, TLE4, LEF1, NFATC1, PRKCH, SMARCD2 and $F B X W 7$ ). These genes encode proteins that are associated with GO: 0001763 (morphogenesis of a branching structure) GO: 0001944 (vasculature development) including involvement in the morphogenesis and function of the endometrial glands $[48,49]$ as well as in the development of uterine vasculature [50]. The altered expression of these genes by the NEB can have a critical role in the regeneration of the endometrium during the postpartum period.

\section{Impact of NEB on genes related to energy metabolism} In SNEB cows, among the 700 genes that are overexpressed in $\mathrm{ST}$, a large proportion were genes classified to encode proteins related to metabolic process (GO: 0008152), macromolecule metabolic process (GO: 0043170) and organic substance metabolic process (GO: 0071704). DEGs were most particularly related to catalytic activity (GO: 0003824) revealing the breakdown of

Table 6 The significant KEGG pathways with over- or under-expressed DEGs for three endometrial cell types (ST, GE and LE) were identified using DAVID database (adjusted $p$-value <0.05)

\begin{tabular}{|c|c|c|c|c|}
\hline cell type & $\begin{array}{l}\text { under/ } \\
\text { over }\end{array}$ & $\begin{array}{l}\text { KEGG Pathway } \\
\text { Id }\end{array}$ & pathway name & genes \\
\hline \multirow[t]{3}{*}{$\begin{array}{l}\text { Stromal } \\
\text { cells }\end{array}$} & $\begin{array}{l}\text { over- } \\
\text { expressed }\end{array}$ & map 04020 & calcium signaling & $\begin{array}{l}\text { P2RX3, ITPKA, ITPR2, CHRM3, ERBB3, CAMK2B, PLN, PLCB4, SLC25A4, HTR2A, MYLK, ADCY8, } \\
\text { TACR1, PTGFR, PTGER3, RYR3, GRIN1 }\end{array}$ \\
\hline & & map 04530 & tight junction & OCLN, IGSF5, MYH14, CLDN23, PRKCZ, MYH11, CGN, TJP3, LLGL2, CLDN8, CLDN3 \\
\hline & $\begin{array}{l}\text { under- } \\
\text { expressed }\end{array}$ & $\begin{array}{l}\text { map } 05162 \\
\text { map } 05164\end{array}$ & $\begin{array}{l}\text { measles and } \\
\text { influenza A }\end{array}$ & JAK1, DDX58, ADAR, STAT1, IFIH1, EIF2AK2, IFNGR2, MX1, OAS1Z, OAS1Y, IRF7 \\
\hline $\begin{array}{l}\text { Glandular } \\
\text { cells }\end{array}$ & $\begin{array}{l}\text { over- } \\
\text { expressed }\end{array}$ & map 04010 & TNF signaling & FOS, SOCS3, JUNB, CCL2 \\
\hline
\end{tabular}




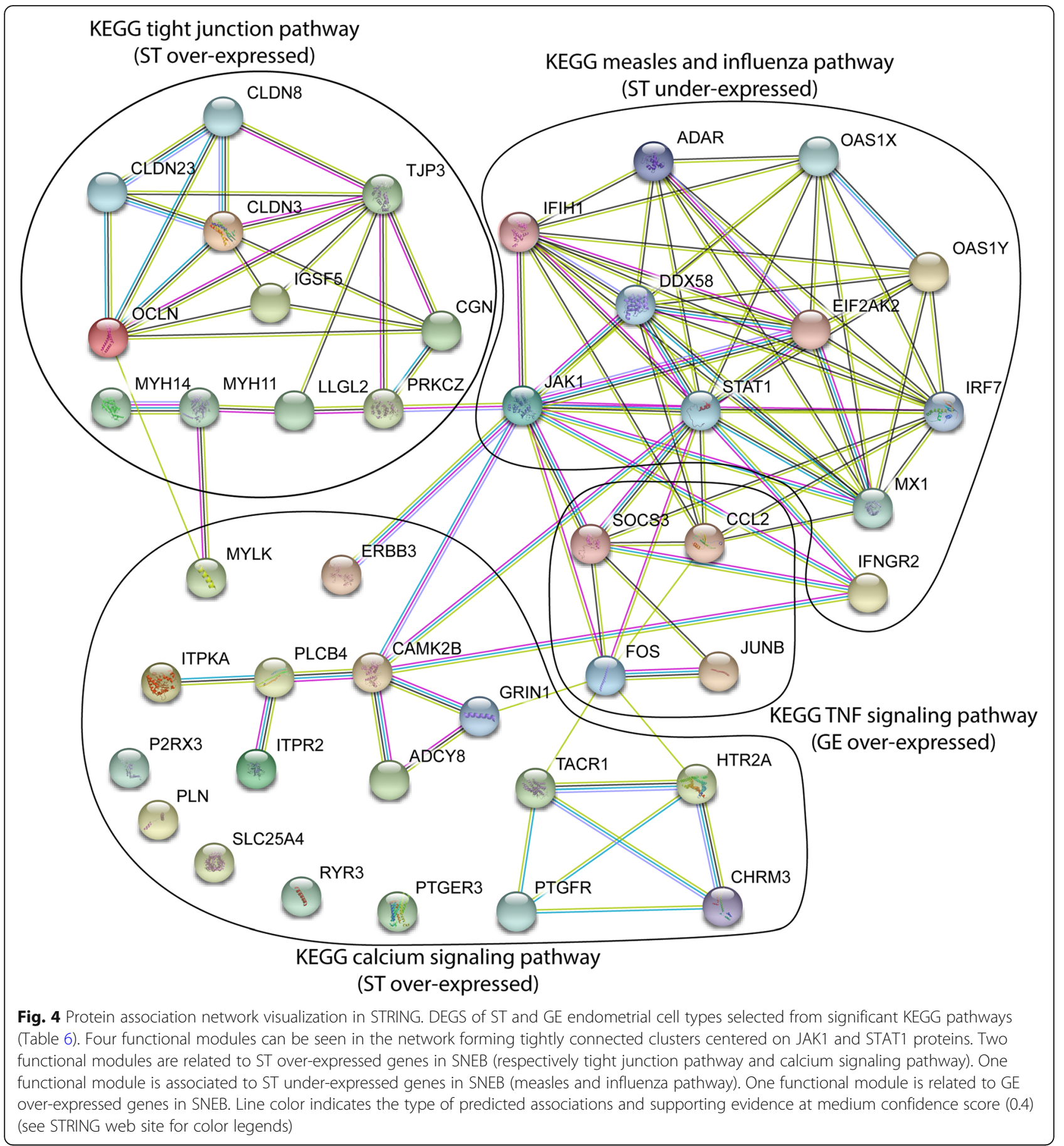

nutrient molecules to supply energy to cells. This suggest that SNEB cows still presented an energy deficit in endometrial cells at time planned for breeding, despite that energy balance is progressively restored. SNEB cows presented also an increased expression of many genes encoding proteins with functions related to lipid metabolism (fatty acids, triglyceride and cholesterol metabolic processes) such as ACSM3, CPT1B, LPL, PPARGC1A, PRKAA2, GGT1, PLA2G10, CYP2B6, CYP2C18, HACD1,
SLC27A6 and PLIN4 in ST. Four of them CYP2B6, CYP2C18, PLA2G10, and GGT1 are involved in arachidonic acid (AA) metabolism. While the release of AA following phospholipase activation is usually engaged in the production of endometrial prostaglandins via cyclooxygenases enzymes, the conversion of AA by CYP enzymes contribute to oxidative stress and inflammation and may not be favourable to endometrial function [51]. The receptivity of fibroblasts to prostaglandins could 
also be modified through their receptors with the observed extreme over-expression of PTGFR mRNA (the second top of over-expressed DEGs in ST) and PTGER3. The over-expression of $S L C 27 A 6$, a gene encoding a fatty acid binding protein (FABP) [52] and PLIN4, which controls intra-cellular lipid droplet-associated proteins, are consistent with earlier findings in obese mice and human $[53,54]$. Our data showing associations between over-expression of these genes with increased plasma NEFA concentrations are consistent with the overexpression of genes of the PLIN family found in the endometrium of low fertility heifers [47]. Taken together, this information suggests that up-regulation of genes involved in lipid uptake in ST of SNEB cows, associated with elevated NEFA concentration during the peri-parturient period may be unfavourable to fertility in post-partum cows. Increased gene expression from the solute carrier family in ST from SNEB cows (such as SLC2A12, SLC45A2 and SLC35A3), which encode proteins involved in carbohydrate transportation, could be seen as a compensatory mechanism as the underexpression of the glucose transporter (SLC2A1) mRNA was detected in endometrial tissue of subfertile dairy cows [55].

\section{Impact of NEB on genes related to growth factors}

Interestingly, expression of genes associated with IGFinsulin signaling, such as IGF1R and IGF2BP2, was higher in SNEB cows. On the contrary, IGFBP2, GDF6, EDIL3 and TGFBI were under-expressed in ST of SNEB cows. The expression of IGFs were detected in the uterine stroma especially in the caruncular areas of cyclic cows [56]. As suggested in the above-referred study and by others [40], the dysregulation of genes related to insulin-like growth factors function may delay tissue remodelling during the post-partum period. In our study, the importance of those changes on matrix metalloproteinase (MMP) appeared limited as only one gene of the MMPs family (MMP19) was under-expressed in ST of SNEB cows. However, 9 closely related genes coding for proteins involved in the degradation of the cellular matrix and tissue remodelling were also under-expressed in the SNEB cows. On the contrary, growth factor receptors such as GRB7, GRB14 and FGFR2, which are known as stromal-derived paracrine stimulators of epithelial proliferation, were over-expressed in ST of SNEB. This increase may be a mechanism for compensating endometrial epithelial defects in order to achieve uterine receptivity [57]. In bovine species, gene expression of FGFs and their receptors is upregulated during pregnancy and these factors stimulate interferon-tau (IFN-T) production during the pre-attachment phase of conceptus development [58]. The increase of transcripts encoding proteins of the cyclin family (CCND3 and CCNB1) in ST of SNEB cows may also be associated with the modifications of proliferative properties and tissue differentiation in the endometrium for preparing embryo implantation [59]. Our results show that NEB status influences both the over-expression and underexpression of genes encoding numerous different growth factors. However, further studies are needed to decipher the consequences of these changes and how they may affect fertility.

\section{Impact of NEB on genes related to inflammatory responses}

Nearly 20 genes belonging to two pathways [cytokine signaling in immune system pathway (R-BTA-1280215) and inflammation mediated by chemokine and cytokine signaling pathway (P00031)] displayed reduced transcripts in ST of SNEB. Among these genes JAK1 and STAT1 have been associated with both IFN- $\gamma$ and IFN $\alpha /$ $\beta$ endometrial receptors [60]. It may be hypothesized that the reduced-expression of JAK1 and STAT1 may alter JAK/STAT signaling and immune response in stromal cells. Indeed, a large number of IFN-inducible genes (R-BTA-877312), such as MX1, MX2, IFI44, IFI6, IFIH1, IFIT1, IFITM2 and IFNGR2 were under- expressed in ST of SNEB cows. These findings are different from previous observations showing over-expression of $M X 1$ and $M X 2$ genes in the full endometrium of SNEB cows during early postpartum [12]. The specificity of stromal cell response to SNEB, may explain differences between studies, however due to the lack of effect on GE, these discrepancies may result also from differences in time post-partum and severity of NEB. The glandular epithelium plays a major role in the activation of the innate immune system as reviewed by [61]. In our study, most of the DEGs in GE related to chemokines, immune response processes, TLRs and TNF signaling pathways, such as CCL2, CCL3, CCL4, CCL11, FOS, JUNB, and SOCS3 were strongly over-expressed in SNEB cows. Some of those genes belonged to the $\mathrm{C}-\mathrm{C}$ motif chemokine ligands (CCLs) family and play an important role in monocyte recruitment in the endometrium [62]. Increased expression of CCL2 mRNA was found associated with lipid accumulation induced uterine inflammation in obese rats [63]. The present results are similar with previous studies performed with full endometrial tissue, showing the up-regulation of inflammatory response genes in SNEB cows [40]. This is also consistent with several studies in other mammals showing that metabolic imbalance, increased lipolysis and most particularly NEFAs, play essential functions in the activation of TNF and TLRs signaling to promote the release of proinflammatory molecules $[64,65]$. Taken together, these studies and our present findings suggest that SNEB and NEFAs activate pro-inflammatory pathways in the 
glandular epithelium and stromal cells. On the contrary, in luminal epithelium, the adaptive immune response (B cell-mediated immunity) and innate immunity, was represented by under-expressed genes such as tracheal antimicrobial peptide $(T A P)$, a beta-defensin gene, which was associated to the NF- $\mathrm{kB}$ pathway [66], and by genes coding for immunoglobulin heavy variable chains that participates in the antigen recognition. These observations need further confirmation. Our results indicate that SNEB induces changes in immune responses, which are different in the three endometrial cell types. They show also that these changes are still present, long after NEB has disappeared suggesting long term effects of metabolic imbalance and NEFAs on the proinflammatory status of the glandular epithelium and the stroma.

\section{Effect of NEB on genes related to maternal-conceptus recognition}

A large set of IFN-inducible genes such as $M X 1, M X 2$, STAT1, JAK1, IFIH1, IFNGR2, ISG15, LY6G6C, OAS1Y, $O A S 1 Z$ and IRF7 were under-expressed in ST of SNEB cows. A weaker expression of those genes that encode proteins involved in IFN-T signaling could account for the decreased endometrium-related fertility in SNEB cows. In pregnant ruminants, IFN-T is the main pregnancy recognition signal [67], that allows the persistence of the corpus luteum and maintaining elevated progesterone concentrations by blocking oxytocin signaling and PGF2 $\alpha$ secretion [68]. Oxytocin signaling has been associated with the maintenance of gap-junctions in luteal tissue [69] and intracellular calcium release in endometrial cells [70]. Differentially expressed genes and our STRING protein-protein network revealed in ST of SNEB cows showed an increase in expression of six genes encoding proteins belonging to the oxytocin signaling pathway namely PLCB4, $A D C Y 8, C A M K 2 B$, ITPR2, and MYLK (Fig. 4). These changes are consistent with the over-expression of 10 genes related to tight junction such as MYH14, MYH11, PRKCZ, OCLN, CGN, IGSF5, TJP3, CLDN3, CLDN8 and CLDN23. Overrepresentation of oxytocin signaling genes together with under-expression of genes involved in pregnancy maintenance suggest a potential weakness of antiluteolytic mechanisms in the SNEB group. The changes in ST are consistent with downstream changes related to PGF2 $\alpha$ produced by both endometrial epithelial and stromal cells [71]. Furthermore the deregulation of this signaling pathway in SNEB cows is supported by changes in levels of PTGFR mRNA, which was over-expressed in ST but under-expressed in GE. In addition, other important genes encoding proteins with established functions critical for implantation such as IL1RAP, SOSC3 and AREG were found to be differentially expressed in SNEB cows.
We observed a lower expression of the IL1RAP gene in ST of SNEB cows. The IL1RAP protein is a necessary part of the interleukin 1 receptor complex and is regulated by interleukin 1 beta (IL-1 $\beta$ )-dependent signaling. The over-expression of IL1R and IL1RAP mRNAs under IL- $1 \beta$ regulation has been reported in the pig endometrium at day 12 of pregnancy to stimulate the expression of PTGS1 and PTGS2 genes which encode key enzymes for PGE2 and PGF2 $\alpha$ synthesis [72]. Blocking IL1R signaling with an IL-1 receptor antagonist led to implantation failure in mice [73]. The reduced expression of IL1RAP in ST of SNEB cows may compromise the establishment of pregnancy, but this deserves further investigation in the cow. SOCS family genes (SOCS1-7) inhibit cytokine signaling through the JAK-STAT pathway and regulate IFNs, growth factors and hormones which are critical for implantation [74]). SOCS1-3 mRNAs are over-expressed at time of implantation in the endometrium of pregnant cows and their expression was induced by IFN-tau in endometrial cells in vitro [75]. The overexpression of SOCS3 mRNA in GE may contribute to down regulate the JAK/STAT signalling pathway in the neighbouring ST cells, as reported above. AREG was over-expressed in GE of SNEB cows. AREG gene is known as an epidermal growth factor receptor and is involved in cell growth, proliferation, differentiation and migration. It is highly expressed in luminal and glandular epithelium during the secretory phase of menstrual cycle and early pregnancy in human and primate [76]. As for SOCS3, it could be speculated that the overexpression of AREG mRNAs in GE may be part of a compensatory mechanisms in response to the increased expression of cytokines in these cells. It would be interesting to compare the amplitude of over-expression of SOCS3 and AREG observed in the present situation (luteal phase under cyclic conditions) with levels during pregnancy to evaluate possible impacts of NEB on implantation.

\section{Conclusion}

The present study provides novel and specific information about differential gene expression in three endometrial cell types from post-partum dairy cows. We show that the impacts of negative energy balance on the gene expression of endometrial cells are cell type-specific. Major and specific changes in gene expression were observed in stromal cells illustrating dysregulation of metabolic processes especially lipid and carbohydrate metabolism, cytoskeleton and cell adhesion properties. Altered gene expression of endometrial epithelial cells under SNEB condition was related to activation of proinflammatory responses via chemokine pathway in GE, whereas down-regulation on adaptive immunity and defence mechanism were found in LE. Strong changes in 
the expression of genes encoding proteins involved in prostaglandin production and maternal-conceptus recognition was found in ST and in GE. Considering the above and the crucial role of IFN-tau for embryo implantation and maintenance of pregnancy, our hypothesis is that the under-expression of IFN-tau responsive genes associated with the increased expression to oxytocin and PGF $2 \alpha$ related genes may be detrimental for the establishment of pregnancy in SNEB cows. The changes in gene expression induced by NEB in LE should be considered as preliminary and needs further confirmation whereas the specific response of ST and GE to NEB paves the way for functional studies relating the importance of these changes for the establishment of pregnancy.

\section{Methods}

\section{Animals and experimental design}

This study was approved by the Uppsala Animal Experiment Ethics Board (application C329/12, PROLIFIC). After the study was conducted all cows have been kept in usual farm living conditions. All studies were conducted at the Swedish Livestock Research Centre in L vsta, Uppsala, Sweden. The animals were kept in a loose housing barn with a voluntary milking system (VMS, DeLaval, Tumba, Sweden), and had free access to drinking water. The current paper reports the specific impacts of post-partum negative energy balance (NEB) on stromal, glandular and luminal epithelial cells whereas a companion paper based on the same biological material reported the differences of the transcriptome between cell-types [33]. Second lactation cows of the Swedish Red breed (SRB; $n=12$ ) were fed two different diets i.e. i) high-energy diet (control, $n=6$ ) targeting $35 \mathrm{~kg}$ energy-corrected milk (ECM) and ii) low-energy diet targeting $(n=6) 25 \mathrm{~kg}$ energy-corrected milk (ECM) which was achieved by giving to these cows $50 \%$ concentrate. For each cow, the differential diets were given between 30 days pre-partum and 120 days post-partum. The dietary details, management conditions and relationships with metabolic response and NEB profiles were previously described [35]. During the experiment, consumption of concentrate was individually adjusted with an automatic feeding machine while forage was fed ad libitum. All cows initially recruited in the experiment were checked for uterine health by using both clinical examination, including ultra-sound examination and endometrial cytology. All cows included in further experiments (synchronization of estrus followed by uterine biopsies in view of LCM) had no clinical signs of uterine disease [77]. They presented less than 10\% (four cows had percentages of immune cells between 7 and 10\%, and all other cows presented less than $5 \%$ of immune cells counted from a total of 400 cells) of immune cells from endometrial cytobrush at 42-45 days post-partum, according to [78]. At day 60 after calving, estrous was synchronized using an intra-vaginal progesterone device (CIDR, Zoetis, Parsippany, NJ, USA) for a week followed by i.m. injection of $500 \mu \mathrm{g}$ of prostaglandin analog (Estrumate ${ }^{\oplus}$ MSD animal health, Madison, NJ, USA) intramuscular as described [79]. Fifteen days after visual oestrus detection, endometrial tissue biopsies were collected under epidural anesthesia with $0.5 \mathrm{mg} / \mathrm{kg}$ of $1 \%$ lidocaine hydrochloride (1\% Xylocaine ${ }^{\ominus}$, Astra Zeneca, Cambridge, UK). Timeline for sampling and analysis of phenotypic responses are presented in supplemental Figure S1. Biopsies were collected at day 15 of the cycle, i.e. at a time progesterone, concentrations which modulate temporal changes in endometrial gene expression are high (reviewed by Forde et al. [23]. This limits also possible individual differences in the dynamics of progesterone patterns associated with luteolysis, which may occur later on.

\section{Energy balance (EB) calculation and classification}

The energy balance (EB) (residual feed intake (RFI) expressed in MJ/day) was calculated as the difference between energy consumed and energy used for milk production, body maintenance, growth and pregnancy for each individual cow. Calculations were performed once every week from first week after calving to day 120 as described in [35]. All data used were routinely recorded in the university herd and energy balance calculation was performed with NorFor used as the reference system in the Nordic countries. Based on the analysis of NEB data, 9 out of 12 cows with the most differentiated profiles were classified into two NEB groups with either a mild negative energy balance (MNEB) group $(n=5)$ or a severe negative energy balance (SNEB) group $(n=4)$. Endometrial biopsy samples from these nine cows were subsequently used for LCM and RNA sequencing. Residual feed intake values in the first week postpartum of these nine cows ranged from -52.77 to $21.26 \mathrm{MJ} /$ day and means ( \pm s.e.m.) of $1.30 \pm 6.35$ and $-29.48 \pm 7.10$ $\mathrm{MJ} /$ day were observed in the MNEB and SNEB groups, respectively.

\section{Body condition score (BCS) and plasma NEFA measurements}

Body condition score (BCS) was evaluated and recorded by the same person every 2 weeks, from 30 days prepartum until 120 days post-partum. BCS was used on a 5 point scale with 0.5 point increments, $1=$ very lean to $5=$ fat [80]. Blood samples were taken every 2 weeks from the coccygeal vein in EDTA containing tubes (BD Vacutainer, Kremsmünster, Austria) from 30 days prepartum to 56 days post-partum and then centrifuged at $4000 \mathrm{~g}$ for $10 \mathrm{~min}$ at $4{ }^{\circ} \mathrm{C}$. Following centrifugation, 
plasma samples were distributed into $0.5 \mathrm{~mL}$ aliquots and stored in $-20{ }^{\circ} \mathrm{C}$ until NEFA analyses were performed. NEFA concentrations were measured in duplicate by using a non-esterified fatty assay kit (Bio Scientific Corporation, Austin, TX, USA) with detection range $0-4 \mathrm{mM}$. The intra- and inter-assay variability was $4.19 \pm 3.99 \%$ and $2.63 \pm 1.08 \%$, respectively.

\section{Milk progesterone measurements and estrous cycle stage at time of biopsies}

Whole milk samples were collected by the automatic milking machine, VMS (DeLaval) three times per week from Day 7 to Day 120 after calving. Milk progesterone concentrations were measured with a commercial enzyme-linked immunosorbent assay (ELISA) (Ridge way 'M' kit, Ridgeway Science, Gloucester, UK) as previously described [35]. The progesterone concentration profile was used to determine the estrous cycle stage at the time of biopsy sampling. All cows selected were in the luteal phase at time of endometrial biopsy as shown by their mean ( \pm s.e.m.) progesterone concentration $(8.78 \pm 2.12 \mathrm{ng} / \mathrm{mL}$; range from 6.66 to $10.90 \mathrm{ng} / \mathrm{ml})$.

\section{Collection of endometrial biopsies}

Endometrial biopsies were collected from the uterine horn ipsilateral to the corpus luteum by using Kevorkian-Younge uterine biopsy forceps (Alcyon, Paris, France). Biopsies were cut into three pieces (sizes $\approx 4 \times$ $4 \mathrm{~mm}^{2}$ ) and were handled as described [33]. Biopsies embedded in optimal cutting temperature (OCT) compound (VWR, Radnor, PA, USA) were $8 \mu \mathrm{m}$ sectioned with a cryostat (Leica CM1860 Cryostat, Wetzlar, Germany) at $-20^{\circ} \mathrm{C}$ under RNA-free conditions.

\section{Laser capture microdissection (LCM) and RNA isolation}

All procedures used were as previously reported [33, 81]. The LCM process was performed by using an ArcturusXT $^{\mathrm{Tn}}$ Laser Capture Microdissection System and software (Applied Biosystems ${ }^{\circ}$, Arcturus, ThermoFisher Scietific, Waltham, MA, USA), within $1 \mathrm{~h}$ to avoid RNA degradation. Luminal epithelial cells (LE), glandular epithelial cells (GE) and stromal cells (ST) were harvested in sufficient numbers to obtain at least $5 \mathrm{ng}$ of total RNA for each endometrial cell type. Total RNA from LCM samples was isolated and mRNA purified using the PicoPure ${ }^{\mathrm{Tm}}$ RNA isolation kit (KIT0202, Arcturus) following the manufacturer's protocol. RNA integrity value (RIN values) and quantity were evaluated using the Pico RNA chip on the Agilent 2100 Bioanalyzer (Agilent technologies, Santa Clara, CA, USA). Mean RNA integrity (RIN) values obtained from LCM samples and from the full tissue samples issued from the same biopsy were similar (paired T-test; Table S2).

\section{RNA sequencing and data analysis}

RNA sequencing libraries prepared from 24 samples (number of samples in each NEB group and endometrial cell types presented in Table S2) were prepared and sequenced on GenomEast Platform (IGBMC, Cedex, France; http://genomeast.igbmc.fr/). Libraries were built using the Clontech SMART-Seq v4 Ultra Low Input RNA kit for Sequencing as described previously [33]. Sequencing was performed on an Illumina HiSeq 4000 with $50 \mathrm{bp}$ paired-end reads. Image analysis and base calling were performed using RTA 2.7.3 and bcl2fastq 2.17.1.14. All steps of the analysis were carried out as described in a sister paper [33]. Gene level exploratory analysis and differential expression were performed using the RNAseq workflow described by [82] and the update version https://www.bioconductor.org/help/ course-materials/2017/CSAMA/labs/2-tuesday/lab-03rnaseq/rnaseqGene_CSAMA2017.html. The Salmon method [83] was used to quantify transcript abundance [83]. After quantifying RNA-seq data, tximport method [84] ( $\mathrm{R}$ package version 1.8.0) was used to import Salmon's transcript-level quantifications to the downstream DESeq2 package ( $R$ package, version 1.20.0) for analysis of differential expressed genes (DEGs) with the statistical method proposed [85]. Principal component analysis was performed with DESeq2 and with FactoMineR ( $R$ package, version 1.4.1) using the variance stabilizing transformation output files from DESeq2. Heatmap was generated in $\mathrm{R}$ software using the pheatmap package (version 1.0.12) and Venn diagrams were plotted with VennDiagram package (1.6.20). DEGs of specificendometrial cell samples were identified in comparison between SNEB and MNEB group with an adjusted $p$ value of 0.05 . Volcano plot was applied to gene lists of each endometrial cell type considering the $\log 2$ fold change between SNEB and MNEB on the $x$ axis and the negative $\log 10$ of the adjusted $p$-value on the $y$ axis.

\section{Gene ontology and KEGG pathway analysis}

Lists of over- or under-expressed DEGs between SNEB and MNEB were annotated into three categories of Gene Ontology (GO) pathways such as biological process (BP), cellular component $(\mathrm{CC})$ and molecular function (MP) using PANTHER classification system (Protein Analysis THrough Evolutionary Relationships version 14.0, http:// pantherdb.org).. Moreover, the analysis of enriched Kyoto Encyclopedia of Genes and Genomes (KEGG) pathways was performed. If a KEGG pathway was determined to be significantly enriched (Benjamini- adjusted $p$-value $<0.05)$, this significant process/pathway was reported. By using DEGs which are involved in significant KEGG pathways, a molecular interaction network analysis was generated by using STRING database (STRING version 11) [86] at medium confidence level (0.4) for 
giving an overview of the genes networks and their interactions.

\section{Statistical analysis}

All statistical analyses on BCS and NEFA concentrations were performed with $\mathrm{SAS}^{\circ}$ software version 9.3 [26], using the MIXED procedure for linear mixed models. A repeated effect of time (week ante-/post-partum) within animals was tested. The correlations between test days were accounted for by specifying a correlation structure (spatial power) among residuals to consider that time intervals between samplings were not exactly the same. Backward elimination was used to build the models, excluding non-significant $(p>0.20)$ effects. The residuals from the observations generated from the mixed models were tested for normal distribution using PROC UNIVARIATE in SAS 9.3. Data deviating from a normal distribution were log-transformed. However, to improve clarity the respective log-transformed values are referred to as BCS and NEFA throughout this paper. Sampling times were treated as actual days postpartum in the analysis of the material and presentation of the results. The model used was:

$$
\begin{aligned}
\text { Yijk }= & \mu+\text { NEB GROUP } i+\text { TIME } j \\
& + \text { NEB GROUP } i * \text { TIME } j+\text { eijk }
\end{aligned}
$$

If non-significant, interaction was removed from the model. Least square means (Lsmeans, \pm standard error of the mean, sem) estimated by the models for the two groups of NEB were compared. A contrast option (ESTI MATE and CONTRAST statements under SAS9.3) was used to investigate differences between different combinations of time intervals (Scheffe adjustment for multiple-post ANOVA comparisons).

The results of BCS, NEFA's concentration, and milk progesterone concentration are presented as LSmeans \pm S.E.M. Differences with associated $p$-value $<0.05$ were considered to be significant. In the statistical analysis of transcriptome profiles, generalized linear model was fitted and Wald test were performed to determine which of the observed fold changes were significantly different between severe and mild negative energy balance groups. $p$-values $<0.05$ were considered to identify DEGs according to procedures described by [82].

\footnotetext{
Abbreviations

BCS: Body condition score; CIDR: Controlled internal drug release; DAVI D: Database for annotation, visualization and integrated discovery; DEG: Differentially expressed gene; EB: Energy balance; ECM: Energycorrected milk; Elisa: Enzyme-linked immunosorbent assay; FDR: False discovery rate; GE: Glandular epithelial cell; GO: Gene ontology; KEGG: Kyoto encyclopedia of genes and genomes; LCM: Laser capture microdissection; LE: Luminal epithelial cell; MNEB: Mild energy balance; NEB: Negative energy balance; NEFAs: Non-esterified fatty acids; NorFor: Nordic feed evaluation system; OCT: Optimal cutting temperature coumpound; PANTHER: Protein analysis through evolutionary relationships; PCA: Principal component
}

analysis; PGE2: Prostaglandin-E2; PGF2a: Prostaglandin-F2a; REVIGO: Reduce, visualize gene ontology; RFI: Residual feed intake; RNA: Ribonucleic acid; RNA-Seq: RNA sequencing; SRB: Swedish Red breed; ST: Stromal cell; STRI NG: Search tool for the retrieval of interacting genes/proteins; TPM: Transcripts per million

\section{Supplementary Information}

The online version contains supplementary material available at https://doi. org/10.1186/s12864-021-07713-z.

\section{Additional file 1: Table S1. Lists of differentially expressed genes} between SNEB and MNEB.

Additional file 2: Table S2. Number of samples of each cell type from MNEB and SNEB group. RNA Integrity Number (RIN)] [mean value $( \pm$ s.e.m)] and average number of tissue sections required to obtain at least $10 \mathrm{ng}$ of total RNA in each endometrial cell type.

Additional file 3: Figure S1. Experimental design including 12 cows, From energy balance profiles 9 cows were selected for LCM of endometrial tissue biopsies ( 5 mild NEB and 4 severe NEB cows). An arrow with dash line indicate a timing for BCS measurement and blood sampling for NEFA measurement.

\section{Acknowledgements}

We acknowledge Pierrette Reinaud (INRAE, Jouy en Josas, France) and Olivier Dubois for consulting during the LCM process and RNA analysis. The authors would like to thank the staff of Swedish Research Center, Lövsta, Uppsala, Sweden and Biology of Reproduction, Epigenetic, Environment and Development (BREED), INRA, Jouy en Josas, France for their help and support.

\section{Authors' contributions}

W.C., P.H. and G.C. contributed to the conception and design of the study. S.L., M.R., C.R., C.B. and T.N. contributed to sample collection and preparation. G.C., D.P., Y.G., W.C. and P.H. performed bioinformatics analysis and integration of data. W.C. performed the experiment, sample collection and preparation, data analyses. GA and OS contributed to experimental design and data analyses. W.C., G.C., and P.H. drafted the manuscript. All authors provided critical feedback and helped shape research, analyses and manuscript. GC and PH are both senior co-authorship. The author(s) read and approved the final manuscript.

\section{Funding}

This work was funded by from European Union [FP7-KBBE-2012-6, Prolific (Pluridisciplinary study for a RObust and sustainabLe Improvement of the Fertility In Cows), Grant agreement number 311776 for animals, reagents, sequencing and travel. WC was supported by the Rajamangala University of Technology Srivijaya (RMUTSV), Thailand. The funders had no role in study design, data collection, and interpretation, or the decision to submit the work for publication.

\section{Availability of data and materials}

The data discussed in this publication have been deposited in NCBI's Gene Expression Omnibus [87] and are accessible through GEO Series accession number GSE169638 (https://www.ncbi.nlm.nih.gov/geo/query/acc.cgi?acc= GSE169638). The gene accession numbers indicated in the additional files refer to the corresponding Ensembl identifier (https://www.ensembl.org/Bos_ taurus/)(Bos taurus: ARS-UCD1.2). Gene names were retrieved using the Ensembl BioMart tool.

\section{Declarations}

Ethics approval and consent to participate

All experimental protocols were approved by the Uppsala Animal Experiment Ethics Board (application C329/12, PROLIFIC) (Uppsala University, Sweden) and were carried out in accordance with the terms of the Swedish Animal Welfare Act. After the study was completed, all cows were kept alive under normal husbandry conditions. 


\section{Consent for publication}

« Not applicable »

\section{Competing interests}

The authors declare that they have no competing interests.

\section{Author details}

'Department of Clinical Sciences, Swedish University of Agricultural Sciences, SLU, PO Box 7054, 75007 Uppsala, Sweden. ${ }^{2}$ Faculty of Veterinary Science, Rajamangala University of Technolgy Srivijaya (RUTS), Thungyai, Nakhon si thammarat 80240, Thailand. ${ }^{3}$ Université Paris-Saclay, UVSQ, INRAE, BREED, 78350 Jouy-en-Josas, France. ${ }^{4}$ GenomEast Platform CERBM GIE, IGBMC, 67404 Illkirch Cedex, France. ${ }^{5}$ Université Paris-Saclay, INRAE, AgroParisTech, GABI, 78350 Jouy en Josas, France. ${ }^{6}$ Department of Animal Breeding and Genetics, Swedish University of Agricultural Sciences, SLU, PO Box 7023, 75007 Uppsala, Sweden.

\section{Received: 18 January 2021 Accepted: 13 May 2021}

\section{Published online: 18 June 2021}

\section{References}

1. Butler W, Everett R, Coppock C. The relationships between energy balance, milk production and ovulation in postpartum Holstein cows. J Anim Sci. 1981;53(3):742-8. https://doi.org/10.2527/jas1981.533742x.

2. Britt JH, Cushman RA, Dechow CD, Dobson H, Humblot P, Hutjens MF, et al. Invited review: learning from the future-a vision for dairy farms and cows in 2067. J Dairy Sci. 2018;101(5):3722-41. https://doi.org/10.3168/jds.2017-14 025 .

3. Harrison R, Ford S, Young J, Conley A, Freeman A. Increased milk production versus reproductive and energy status of high producing dairy cows1. J Dairy Sci. 1990;73(10):2749-58. https://doi.org/10.3168/jds.S0022-03 02(90)78960-6.

4. Butler WR. Energy balance relationships with follicular development, ovulation and fertility in postpartum dairy cows. Livest Prod Sci. 2003;83(23):211-8. https://doi.org/10.1016/S0301-6226(03)00112-X.

5. Barbat A, Le Mezec P, Ducrocq V, Mattalia S, Fritz S, Boichard D, et al. Female fertility in French dairy breeds: current situation and strategies for improvement. J Reprod Dev. 2010;56(S):S15-21. https://doi.org/10.1262/jrd.1 $056 S 15$.

6. Grummer RR, Mashek DG, Hayirli A. Dry matter intake and energy balance in the transition period. Vet Clin Food Anim Pract. 2004;20(3):447-70. https:// doi.org/10.1016/j.cvfa.2004.06.013.

7. Senatore E, Butler W, Oltenacu P. Relationships between energy balance and post-partum ovarian activity and fertility in first lactation dairy cows. Anim Sci. 1996;62(1):17-23. https://doi.org/10.1017/S1357729800014260.

8. Swangchan-Uthai T, Chen QS, Kirton SE, Fenwick MA, Cheng ZR, Patton J, et al. Influence of energy balance on the antimicrobial peptides S100A8 and S100A9 in the endometrium of the post-partum dairy cow. Reproduction. 2013;145(5):527-39. https://doi.org/10.1530/REP-12-0513.

9. Butler W, Smith R. Interrelationships between energy balance and postpartum reproductive function in dairy cattle. J Dairy Sci. 1989;72(3):76783. https://doi.org/10.3168/jds.S0022-0302(89)79169-4.

10. Esposito G, Irons PC, Webb EC, Chapwanya A. Interactions between negative energy balance, metabolic diseases, uterine health and immune response in transition dairy cows. Anim Reprod Sci. 2014;144(3-4):60-71. https://doi.org/10.1016/j.anireprosci.2013.11.007.

11. Leroy JL, De Bie J, Jordaens L, Desmet K, Smits A, Marei WF, et al. Negative energy balance and metabolic stress in relation to oocyte and embryo quality: an update on possible pathways reducing fertility in dairy cows. Anim Reprod. 2017;14:497-506

12. Wathes DC, Cheng ZR, Chowdhury W, Fenwick MA, Fitzpatrick R, Morris DG, et al. Negative energy balance alters global gene expression and immune responses in the uterus of postpartum dairy cows. Physiol Genomics. 2009; 39(1):1-13. https://doi.org/10.1152/physiolgenomics.00064.2009.

13. Wathes DC, Clempson AM, Pollott GE. Associations between lipid metabolism and fertility in the dairy cow. Reprod Fert Develop. 2013;25(1): 48-61. https://doi.org/10.1071/RD12272.

14. Bauersachs S, Simintiras CA, Sturmey RG, Krebs S, Bick J, Blum H, et al. Effect of metabolic status on conceptus-maternal interactions on day 19 in dairy cattle: II. Effects on the endometrial transcriptome. Biol Reprod. 2017:97(3): 413-25. https://doi.org/10.1093/biolre/iox095.

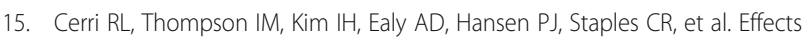
of lactation and pregnancy on gene expression of endometrium of Holstein cows at day 17 of the estrous cycle or pregnancy. J Dairy Sci. 2012;95(10): 5657-75. https://doi.org/10.3168/jds.2011-5114.

16. Thompson IM, Cerri RL, Kim IH, Ealy AD, Hansen PJ, Staples CR, et al. Effects of lactation and pregnancy on metabolic and hormonal responses and expression of selected conceptus and endometrial genes of Holstein dairy cattle. J Dairy Sci. 2012;95(10):5645-56. https://doi.org/10.3168/jds.20115113.

17. Chankeaw W, Guo Y, Båge R, Svensson A, Andersson G, Humblot P. Elevated non-esterified fatty acids impair survival and promote lipid accumulation and pro-inflammatory cytokine production in bovine endometrial epithelial cells. Reproduction, Fertility and Development; 2018.

18. Ohtsu A, Tanaka H, Seno K, Iwata H, Kuwayama T, Shirasuna K. Palmitic acid stimulates interleukin-8 via the TLR4/NF-KB/ROS pathway and induces mitochondrial dysfunction in bovine oviduct epithelial cells. Am J Reprod Immunol. 2017;77(6):e12642. https://doi.org/10.1111/aji.12642.

19. Marchi T, Braakman RBH, Stingl C, Duijn MM, Smid M, Foekens JA, et al. The advantage of laser-capture microdissection over whole tissue analysis in proteomic profiling studies. PROTEOMICS. 2016;16(10):1474-85. https://doi. org/10.1002/pmic.201600004

20. Martin L, Finn C. Hormonal regulation of cell division in epithelial and connective tissues of the mouse uterus. J Endocrinol. 1968;41(3):363-71. https://doi.org/10.1677/joe.0.0410363.

21. Bazer FW, Burghardt RC, Johnson GA, Spencer TE, Wu G. Mechanisms for the establishment and maintenance of pregnancy: synergies from scientific collaborationst. Biol Reprod. 2018;99(1):225-41. https://doi.org/10.1093/ biolre/ioy047.

22. Gray CA, Bartol FF, Tarleton BJ, Wiley AA, Johnson GA, Bazer FW, et al. Developmental biology of uterine glands. Biol Reprod. 2001;65(5):1311-23. https://doi.org/10.1095/biolreprod65.5.1311.

23. Forde $\mathrm{N}$, Lonergan $\mathrm{P}$. Transcriptomic analysis of the bovine endometrium: what is required to establish uterine receptivity to implantation in cattle? J Reprod Dev. 2012;58(2):189-95. https://doi.org/10.1262/jrd.2011-021.

24. Fortier M, Guilbault L, Grasso F. Specific properties of epithelial and stromal cells from the endometrium of cows. J Reprod Fertil. 1988;83(1):239-48. https://doi.org/10.1530/jrf.0.0830239.

25. Schaefer TM, Desouza K, Fahey JV, Beagley KW, Wira CR. Toll-like receptor (TLR) expression and TLR-mediated cytokine/chemokine production by human uterine epithelial cells. Immunology. 2004;112(3):428-36. https://doi. org/10.1111/j.1365-2567.2004.01898.x.

26. Niklaus AL, Pollard JW. Mining the mouse transcriptome of receptive endometrium reveals distinct molecular signatures for the luminal and glandular epithelium. Endocrinology. 2006;147(7):3375-90. https://doi.org/1 0.1210/en.2005-1665.

27. Gray CA, Taylor KM, Ramsey WS, Hill JR, Bazer FW, Bartol FF, et al. Endometrial glands are required for preimplantation conceptus elongation and survival. Biol Reprod. 2001;64(6):1608-13. https://doi.org/10.1095/ biolreprod64.6.1608.

28. Demir R, Kayisli U, Celik-Ozenci C, Korgun E, Demir-Weusten A, Arici A. Structural differentiation of human uterine luminal and glandular epithelium during early pregnancy: an ultrastructural and immunohistochemical study. Placenta. 2002;23(8-9):672-84. https://doi.org/10.1053/plac.2002.0841.

29. Fazleabas A, Bazer F, Roberts RM. Purification and properties of a progesterone-induced plasmin/trypsin inhibitor from uterine secretions of pigs and its immunocytochemical localization in the pregnant uterus. J Biol Chem. 1982;257(12):6886-97. https://doi.org/10.1016/S0021-9258(1 8)34513-7.

30. Scaravaggi I, Borel N, Romer R, Imboden I, Ulbrich SE, Zeng S, et al. Cell type-specific endometrial transcriptome changes during initial recognition of pregnancy in the mare. Reproduction, fertility and development; 2018.

31. Hood BL, Liu B, Alkhas A, Shoji Y, Challa R, Wang G, et al. Proteomics of the human endometrial glandular epithelium and stroma from the proliferative and secretory phases of the menstrual cycle1. Biol Reprod. 2015;92(4):106, 101-108-106, 101-108. https://doi.org/10.1095/biolreprod.114.127217.

32. Brooks K, Burns GW, Moraes JG, Spencer TE. Analysis of the uterine epithelial and conceptus transcriptome and luminal fluid proteome during the periimplantation period of pregnancy in sheep. Biol Reprod. 2016;95(4):88 https://doi.org/10.1095/biolreprod.116.141945.

33. Chankeaw W, Lignier S, Richard C, Ntallaris T, Raliou M, G. Y, et al. Analysis of the transcriptome of bovine endometrial cells isolated by laser micro- 
dissection (1): specific signatures of stromal, glandular and luminal epithelial cells. BMC Genomics. 2021; https://doi.org/10.1186/s12864-021-07712-0.

34. Adewuyi AA, Gruys E, van Eerdenburg FJ. Non esterified fatty acids (NEFA) in dairy cattle. A review. Vet Q. 2005;27(3):117-26. https://doi.org/10.1080/01 652176.2005 .9695192$.

35. Ntallaris T, Humblot P, Bage R, Sjunnesson Y, Dupont J, Berglund B. Effect of energy balance profiles on metabolic and reproductive response in Holstein and Swedish red cows. Theriogenology. 2017;90:276-83. https://doi.org/10.1 016/j.theriogenology.2016.12.012.

36. Butler ST, Marr AL, Pelton SH, Radcliff RP, Lucy MC, Butler WR. Insulin restores $\mathrm{GH}$ responsiveness during lactation-induced negative energy balance in dairy cattle: effects on expression of IGF-I and GH receptor 1A. J Endocrinol. 2003;176(2):205-17. https://doi.org/10.1677/joe.0.17602 05.

37. Jorritsma R, Cesar ML, Hermans JT, Kruitwagen CL, Vos PL, Kruip TA. Effects of non-esterified fatty acids on bovine granulosa cells and developmental potential of oocytes in vitro. Anim Reprod Sci. 2004;81(3-4):225-35. https:// doi.org/10.1016/j.anireprosci.2003.10.005.

38. Van Hoeck V, Sturmey RG, Bermejo-Alvarez P, Rizos D, Gutierrez-Adan A, Leese $\mathrm{HJ}$, et al. Elevated non-esterified fatty acid concentrations during bovine oocyte maturation compromise early embryo physiology. PLoS One. 2011;6(8):e23183. https://doi.org/10.1371/journal.pone.0023183.

39. Fenwick MA, Llewellyn S, Fitzpatrick R, Kenny DA, Murphy JJ, Patton J, et al. Negative energy balance in dairy cows is associated with specific changes in IGF-binding protein expression in the oviduct. Reproduction. 2008;135(1): 63-75. https://doi.org/10.1530/REP-07-0243.

40. Wathes DC, Cheng Z, Fenwick MA, Fitzpatrick R, Patton J. Influence of energy balance on the somatotrophic axis and matrix metalloproteinase expression in the endometrium of the postpartum dairy cow. Reproduction. 2011;141(2):269-81. https://doi.org/10.1530/REP-10-0177.

41. Moran B, Butler ST, Moore SG, MacHugh DE, Creevey CJ. Differential gene expression in the endometrium reveals cytoskeletal and immunological genes in lactating dairy cows genetically divergent for fertility traits. Reprod Fertil Dev. 2017;29(2):274-82. https://doi.org/10.1071/RD15128.

42. Kimmins S, MacLaren LA. Cyclic modulation of integrin expression in bovine endometrium. Biol Reprod. 1999;61(5):1267-74. https://doi.org/10.1095/ biolreprod61.5.1267.

43. Lessey BA, Castelbaum AJ, Buck CA, Lei Y, Yowell CW, Sun J. Further characterization of endometrial integrins during the menstrual cycle and in pregnancy. Fertil Steril. 1994;62(3):497-506. https://doi.org/10.1016/S0015-02 82(16)56937-4

44. Chen $G$, Xin A, Liu $Y$, Shi $C$, Chen J, Tang $X$, et al. Integrins $\beta 1$ and $\beta 3$ are biomarkers of uterine condition for embryo transfer. J Transl Med. 2016; 14(1):303. https://doi.org/10.1186/s12967-016-1052-0.

45. Spencer TE, Bazer FW. Uterine and placental factors regulating conceptus growth in domestic animals. J Anim Sci. 2004;82(E-Suppl):E4-13.

46. Achache $\mathrm{H}$, Revel A. Endometrial receptivity markers, the journey to successful embryo implantation. Hum Reprod Update. 2006;12(6):731-46. https://doi.org/10.1093/humupd/dml004.

47. Killeen AP, Diskin MG, Morris DG, Kenny DA, Waters SM. Endometrial gene expression in high-and low-fertility heifers in the late luteal phase of the estrous cycle and a comparison with midluteal gene expression. Physiol Genomics. 2016;48(4):306-19. https://doi.org/10.1152/physiolgenomics, 00042.2015.

48. Cooke PS, Spencer TE, Bartol FF, Hayashi K. Uterine glands: development, function and experimental model systems. Mol Hum Reprod. 2013;19(9): 547-58. https://doi.org/10.1093/molehr/gat031.

49. Filant J, Spencer TE. Uterine glands: biological roles in conceptus implantation, uterine receptivity and decidualization. Int J Dev Biol. 2014; 58(2-4):107-16. https://doi.org/10.1387/ijdb.130344ts.

50. Bazer FW, Wu G, Spencer TE, Johnson GA, Burghardt RC, Bayless K. Novel pathways for implantation and establishment and maintenance of pregnancy in mammals. Mol Hum Reprod. 2010;16(3):135-52. https://doi. org/10.1093/molehr/gap095.

51. Roman RJ. P-450 metabolites of arachidonic acid in the control of cardiovascular function. Physiol Rev. 2002;82(1):131-85. https://doi.org/10.11 52/physrev.00021.2001.

52. Bionaz M, Loor JJ. ACSL1, AGPAT6, FABP3, LPIN1, and SLC27A6 are the most abundant isoforms in bovine mammary tissue and their expression is affected by stage of lactation. J Nutr. 2008;138(6):1019-24. https://doi.org/1 0.1093/jn/138.6.1019.
53. Chen W, Chang B, Wu X, Li L, Sleeman M, Chan L. Inactivation of Plin4 downregulates Plin5 and reduces cardiac lipid accumulation in mice. Am J Physiol Endocrinol Metab. 2013;304(7):E770-9. https://doi.org/10.1152/a jpendo.00523.2012.

54. Itabe H, Yamaguchi T, Nimura S, Sasabe N. Perilipins: a diversity of intracellular lipid droplet proteins. Lipids Health Dis. 2017;16(1):83. https:// doi.org/10.1186/s12944-017-0473-y.

55. Walker CG, Littlejohn MD, Mitchell MD, Roche JR, Meier S. Endometrial gene expression during early pregnancy differs between fertile and subfertile dairy cow strains. Physiol Genomics. 2012;44(1):47-58. https://doi.org/10.11 52/physiolgenomics.00254.2010.

56. Llewellyn S, Fitzpatrick R, Kenny DA, Patton J, Wathes DC. Endometrial expression of the insulin-like growth factor system during uterine involution in the postpartum dairy cow. Domest Anim Endocrinol. 2008;34(4):391-402. https://doi.org/10.1016/j.domaniend.2007.11.003.

57. Li R, He J, Chen X, Ding Y, Wang Y, Long C, et al. Mmu-miR-193 is involved in embryo implantation in mouse uterus by regulating GRB7 gene expression. Reprod Sci. 2014;21(6):733-42. https://doi.org/10.1177/193371 9113512535.

58. Cooke FN, Pennington KA, Yang Q, Ealy AD. Several fibroblast growth factors are expressed during pre-attachment bovine conceptus development and regulate interferon-tau expression from trophectoderm. Reproduction. 2009;137(2):259-69. https://doi.org/10.1530/REP-08-0396.

59. Tan J, Raja S, Davis MK, Tawfik O, Dey SK, Das SK. Evidence for coordinated interaction of cyclin D3 with p21 and cdk6 in directing the development of uterine stromal cell decidualization and polyploidy during implantation. Mech Dev. 2002;111(1-2):99-113. https://doi.org/10.1016/S0925-4773(01 )00614-1.

60. O'Shea JJ, Gadina M, Schreiber RD. Cytokine signaling in 2002: new surprises in the Jak/Stat pathway. Cell. 2002;109(Suppl):S121-31. https://doi.org/10.1 016/50092-8674(02)00701-8.

61. Wira CR, Grant-Tschudy KS, Crane-Godreau MA. Epithelial cells in the female reproductive tract: a central role as sentinels of immune protection. Am J Reprod Immunol. 2005;53(2):65-76. https://doi.org/10.1111/j.1600-0897.2004. 00248.x.

62. Du MR, Wang SC, Li DJ. The integrative roles of chemokines at the maternal-fetal interface in early pregnancy. Cell Mol Immunol. 2014;11(5): 438-48. https://doi.org/10.1038/cmi.2014.68.

63. Shankar K, Zhong Y, Kang P, Lau F, Blackburn ML, Chen JR, et al. Maternal obesity promotes a proinflammatory signature in rat uterus and blastocyst. Endocrinology. 2011;152(11):4158-70. https://doi.org/1 0.1210/en.2010-1078.

64. Konner AC, Bruning JC. Toll-like receptors: linking inflammation to metabolism. Trends Endocrinol Metab. 2011;22(1):16-23. https://doi.org/10.1 016/j.tem.2010.08.007.

65. Graugnard DE, Moyes KM, Trevisi E, Khan MJ, Keisler D, Drackley JK, et al. Liver lipid content and inflammometabolic indices in peripartal dairy cows are altered in response to prepartal energy intake and postpartal intramammary inflammatory challenge. J Dairy Sci. 2013;96(2):918-35. https://doi.org/10.3168/jds.2012-5676.

66. Lopez-Meza JE, Gutierrez-Barroso A, Ochoa-Zarzosa A. Expression of tracheal antimicrobial peptide in bovine mammary epithelial cells. Res Vet Sci. 2009; 87(1):59-63. https://doi.org/10.1016/..rvsc.2008.12.005.

67. Thatcher WW, Guzeloglu A, Mattos R, Binelli M, Hansen TR, Pru JK. Uterineconceptus interactions and reproductive failure in cattle. Theriogenology. 2001;56(9):1435-50. https://doi.org/10.1016/S0093-691X(01)00645-8.

68. Spencer TE, Johnson GA, Bazer FW, Burghardt RC. Fetal-maternal interactions during the establishment of pregnancy in ruminants. Soc Reprod Fertil Suppl. 2007;64:379-96. https://doi.org/10.5661/rdr-vi-379.

69. Khan-Dawood FS, Yang J, Dawood MY. Hormonal regulation of connexin-43 in baboon corpora lutea. J Endocrinol. 1998;157(3):405-14. https://doi.org/1 0.1677/joe.0.1570405.

70. Blanks AM, Shmygol A, Thornton S. Regulation of oxytocin receptors and oxytocin receptor signaling. Semin Reprod Med. 2007;25(1):52-9. https://doi. org/10.1055/s-2006-956775.

71. Arosh JA, Parent J, Chapdelaine P, Sirois J, Fortier MA. Expression of cyclooxygenases 1 and 2 and prostaglandin E synthase in bovine endometrial tissue during the estrous cycle. Biol Reprod. 2002;67(1):161-9. https://doi.org/10.1095/biolreprod67.1.161.

72. Seo H, Choi Y, Yu I, Shim J, Lee CK, Hyun SH, et al. Analysis of ENPP2 in the uterine endometrium of pigs carrying somatic cell nuclear transfer cloned 
embryos. Asian-Australas J Anim Sci. 2013;26(9):1255-61. https://doi.org/10. 5713/ajas.2013.13158.

73. Simon C, Frances A, Piquette GN, el Danasouri I, Zurawski G, Dang W, et al. Embryonic implantation in mice is blocked by interleukin-1 receptor antagonist. Endocrinology. 1994;134(2):521-8. https://doi.org/10.1210/ endo.134.2.8299552.

74. Krebs DL, Hilton DJ. SOCS proteins: negative regulators of cytokine signaling. Stem Cells. 2001;19(5):378-87. https://doi.org/10.1634/stemcells.1 9-5-378.

75. Carvalho AV, Reinaud P, Forde N, Healey GD, Eozenou C, Giraud-Delville C, et al. SOCS genes expression during physiological and perturbed implantation in bovine endometrium. Reproduction. 2014;148(6):545-57. https://doi.org/10.1530/REP-14-0214

76. Yue ZP, Yang ZM, Wei P, Li SJ, Wang HB, Tan JH, et al. Leukemia inhibitory factor, leukemia inhibitory factor receptor, and glycoprotein 130 in rhesus monkey uterus during menstrual cycle and early pregnancy. Biol Reprod. 2000;63(2):508-12. https://doi.org/10.1095/biolreprod63.2.508.

77. Sheldon IM, Lewis GS, LeBlanc S, Gilbert RO. Defining postpartum uterine disease in cattle. Theriogenology. 2006;65(8):1516-30. https://doi.org/10.101 6/j.theriogenology.2005.08.021.

78. Kasimanickam R, Duffield TF, Foster RA, Gartley CJ, Leslie KE, Walton JS, et al. Endometrial cytology and ultrasonography for the detection of subclinical endometritis in postpartum dairy cows. Theriogenology. 2004;62(1-2):9-23. https://doi.org/10.1016/.jtheriogenology.2003.03.001.

79. Johnson S, Funston R, Hall J, Lamb G, Lauderdale J, Patterson D, Perry G. Protocols for synchronization of estrus and ovulation. Proceedings Applied Reproductive Strategies in Beef Cattle San Antonio, TX. 2010.

80. Edmonson A, Lean I, Weaver L, Farver T, Webster G. A body condition scoring chart for Holstein dairy cows. J Dairy Sci. 1989;72(1):68-78. https:// doi.org/10.3168/jds.S0022-0302(89)79081-0.

81. Bevilacqua C, Makhzami S, Helbling J-C, Defrenaix P, Martin P. Maintaining RNA integrity in a homogeneous population of mammary epithelial cells isolated by laser capture microdissection. BMC Cell Biol. 2010;11(1):95. https://doi.org/10.1186/1471-2121-11-95.

82. Love Ml, Anders S, Kim V, Huber W. RNA-Seq workflow: gene-level exploratory analysis and differential expression. F1000Res. 2015;4:1070.

83. Patro R, Duggal G, Love MI, Irizarry RA, Kingsford C. Salmon provides fast and bias-aware quantification of transcript expression. Nat Methods. 2017; 14(4):417-9. https://doi.org/10.1038/nmeth.4197.

84. Soneson C, Love MI, Robinson MD. Differential analyses for RNA-seq transcript-level estimates improve gene-level inferences. F1000Res. 2015;4: 1521.

85. Love Ml, Huber W, Anders S. Moderated estimation of fold change and dispersion for RNA-seq data with DESeq2. Genome Biol. 2014;15(12):550 https://doi.org/10.1186/s13059-014-0550-8.

86. Szklarczyk D, Gable AL, Lyon D, Junge A, Wyder S, Huerta-Cepas J, et al. STR NG v11: protein-protein association networks with increased coverage, supporting functional discovery in genome-wide experimental datasets. Nucleic Acids Res. 2019;47(D1):D607-13. https://doi.org/10.1093/nar/ gky1131.

87. Edgar R, Domrachev M, Lash AE. Gene expression omnibus: NCBI gene expression and hybridization array data repository. Nucleic Acids Res. 2002; 30(1):207-10. https://doi.org/10.1093/nar/30.1.207.

\section{Publisher's Note}

Springer Nature remains neutral with regard to jurisdictional claims in published maps and institutional affiliations.

Ready to submit your research? Choose BMC and benefit from:

- fast, convenient online submission

- thorough peer review by experienced researchers in your field

- rapid publication on acceptance

- support for research data, including large and complex data types

- gold Open Access which fosters wider collaboration and increased citations

- maximum visibility for your research: over $100 \mathrm{M}$ website views per year

At BMC, research is always in progress.

Learn more biomedcentral.com/submissions 